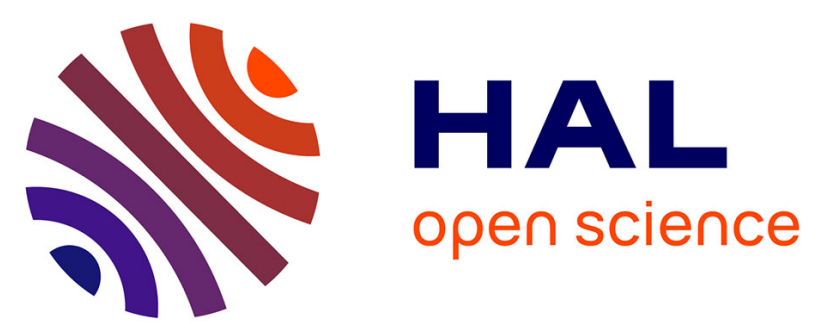

\title{
Efficient synthetic approach to heterocycles possessing the 3,3-disubstituted-2,3-dihydrobenzofuran skelton via diverse palladium-catalyzed tandem reactions
}

\author{
Magali Sklosek-Pinaud, Philippe Diaz, Jean Martinez, Frédéric Lamaty
}

\section{- To cite this version:}

Magali Sklosek-Pinaud, Philippe Diaz, Jean Martinez, Frédéric Lamaty. Efficient synthetic approach to heterocycles possessing the 3,3-disubstituted-2,3-dihydrobenzofuran skelton via diverse palladiumcatalyzed tandem reactions. Tetrahedron, 2007, 63 (16), pp.3340-3349. 10.1016/j.tet.2007.02.035 . hal-00136689

\section{HAL Id: hal-00136689 \\ https://hal.science/hal-00136689}

Submitted on 2 Feb 2021

HAL is a multi-disciplinary open access archive for the deposit and dissemination of scientific research documents, whether they are published or not. The documents may come from teaching and research institutions in France or abroad, or from public or private research centers.
L'archive ouverte pluridisciplinaire HAL, est destinée au dépôt et à la diffusion de documents scientifiques de niveau recherche, publiés ou non, émanant des établissements d'enseignement et de recherche français ou étrangers, des laboratoires publics ou privés. 


\title{
Efficient synthetic approach to heterocycles possessing the 3,3-disubstituted-2,3-dihydrobenzofuran skeleton via diverse palladium-catalyzed tandem reactions
}

\author{
Magali Szlosek-Pinaud, ${ }^{\mathrm{a}, \dagger}$ Philippe Diaz, ${ }^{\mathrm{b}}$ Jean Martinez ${ }^{\mathrm{a}}$ and Frédéric Lamaty ${ }^{\mathrm{a}, *}$ \\ ${ }^{a}$ Laboratoire des Aminoacides, Peptides et Protéines (LAPP), UMR 5810-CNRS-Universités Montpellier 1 et 2 , \\ Place Eugène Bataillon, 34095 Montpellier Cedex 5, France \\ ${ }^{\mathrm{b}}$ Galderma R\&D, 635, route des Lucioles, BP 87, 06902 Sophia Antipolis Cedex, France
}

\begin{abstract}
Various palladium-catalyzed cascade reactions of $O$-alkylated 2-iodophenol were explored in order to synthesize novel dihydrobenzofurans. An efficient tandem cyclization/anion capture reaction was developed to yield 3,3-disubstituted-2,3-dihydrobenzofurans. A small library of these compounds was prepared with a parallel organic synthesizer. A multi-component version of this reaction involving 2-iodophenol, an alkylating agent and a nucleophile, provided the same products. The methoxycarbonyl-substituted heterocyclic ring was hydrolyzed to a free acid, which could be used for further transformations.
\end{abstract}

\section{Introduction}

Naturally occurring substituted-2,3-dihydrobenzofurans are an important class of biologically active oxygencontaining heterocycles. Natural products possessing the dihydrobenzofuran skeleton exhibit a wide range of biological activities. For example (Fig. 1), Megapodiol is an anti-leukaemic agent, ${ }^{1}$ Conocarpan is an anti-cancer agent, ${ }^{2}$ and Furaquinocines are antibiotics. ${ }^{3}$ Some other derived compounds present cytotoxic and anti-protozoal activities. ${ }^{4}$

Therefore, organic chemists have made extensive efforts to develop new chemical processes to produce elaborate heterocyclic structures. ${ }^{5-8}$ Among the variety of new

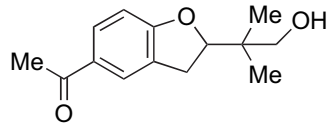

Megapodiol

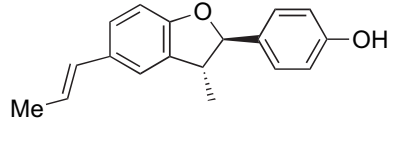

Conocarpan
Figure 1. Structures of biologically active dihydrobenzofurans.

\footnotetext{
* Corresponding author. Fax: +33 (0) 4671448 66; e-mail addresses: frederic.lamaty@univ-montp2.fr; m.szlosek@ism.u-bordeaux1.fr

† Present address: ISM, UMR-CNRS 5255, Groupe Synthèse, Université Bordeaux 1, 351, cours de la liberation, 33405 Talence Cedex, France.
}

synthetic approaches, transition metal-catalyzed reactions are part of the most attractive methodologies, since they can directly lead to complicated molecules from readily accessible starting materials under mild conditions. ${ }^{9}$ Palladium-catalyzed cascades in particular, provide versatile and efficient methods for the assembly of a wide range of organic compounds via carbon-carbon and carbonheteroatom bond formation. ${ }^{10-14}$ These cascades usually proceed under mild conditions and are tolerant of a wide variety of functional groups. They allow the access to a high degree of molecular complexity in a one-pot protocol, where conventional methodology would require multi-step synthesis. ${ }^{15}$ Such reactions minimize reactor time and waste, whilst offering interesting synthetic solutions.

To our knowledge, only few Pd-catalyzed cascade reactions have been used to efficiently build 3,3-disubstituted-2,3-dihydrobenzofurans, using very simple starting materials. ${ }^{16,17}$ In a preliminary study, we have described the first examples of Pd-catalyzed multi-component reactions involving methyl bromomethylacrylate in an allylation followed by another Pd-catalyzed process (Heck and/or Suzuki reactions). ${ }^{18,19}$ We report herein a more extensive study of different $\mathrm{Pd}$-catalyzed cascades starting with a Pd-catalyzed allylic alkylation of 2-iodophenol by methyl bromomethylacrylate, allowing introduction of diversity in a very simple manner (Scheme 1). 


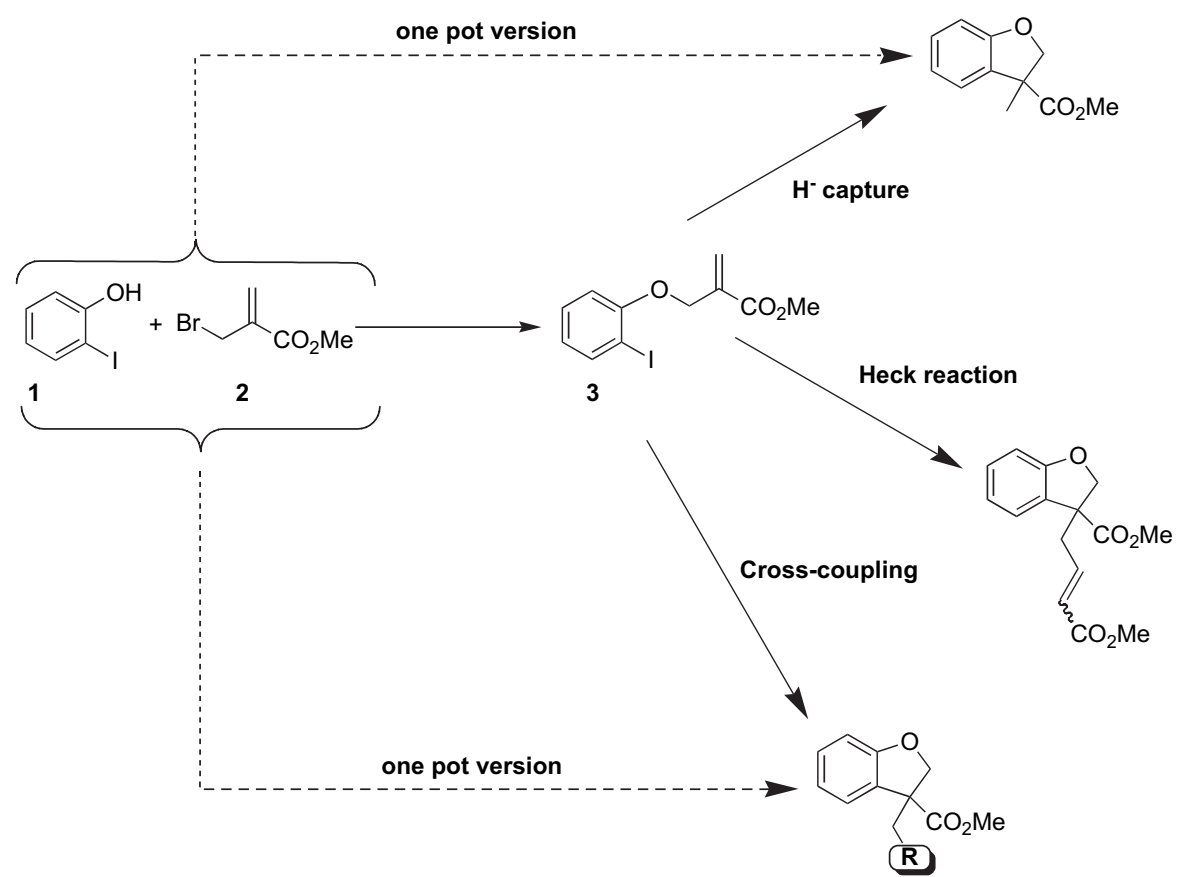

Scheme 1. General strategy for the synthesis of 3,3-disubstituted-2,3-dihydrobenzofuran derivatives.

\section{Results and discussion}

\subsection{Pd-catalyzed tandem cyclization-hydride capture}

The allylic alkylation of 2-iodophenol 1 using methyl bromomethylacrylate 2, and $\mathrm{Cs}_{2} \mathrm{CO}_{3}$ as a base was performed in acetonitrile at $80^{\circ} \mathrm{C}$, leading to the corresponding alkylated compound 3 in $89 \%$ yield (Scheme 2). Pd-catalyzed tandem cyclization-hydride capture was achieved using a mixture of tributylamine and formic acid as a hydride source, and $\operatorname{Pd}(\mathrm{OAc})_{2}$ as catalyst, in acetonitrile at $60{ }^{\circ} \mathrm{C}$. Thus, the 3,3disubstituted-2,3-dihydrobenzofuran $\mathbf{4}$ was obtained in $80 \%$ yield from a 5-exo-trig cyclization followed by trapping of the resulting alkylpalladium complex with a hydride (Scheme 2). To get the corresponding carboxylic acid, compound $\mathbf{4}$ was hydrolyzed with aqueous sodium hydroxide in a mixture of dioxane/water (9/1) providing $\mathbf{5}$ in $70 \%$ yield (Scheme 2).

This sequence (alkylation, cyclization/hydride capture, and saponification) was performed on a gram scale with an overall yield of $45 \%$. Furthermore, we decided to realize this reaction sequence in a one-pot version, starting from 1 and 2. Compound 4 was obtained in $40 \%$ yield with the advantage of avoiding intermediate purification using sodium formate as a hydride source, $\mathrm{Pd}(\mathrm{OAc})_{2}$ as a catalyst and $\mathrm{Cs}_{2} \mathrm{CO}_{3}$ as base in the presence of tetrabutylammonium chloride $\left(n-\mathrm{Bu}_{4} \mathrm{NCl}\right)$, in acetonitrile, at $80^{\circ} \mathrm{C}$. Initial reduction of $\mathrm{Pd}(\mathrm{OAc})_{2}$ with $\mathrm{HCOONa}$ generates the active $\operatorname{Pd}(0)$ species denoted $\operatorname{Pd}(0) \mathrm{L}_{n}$ in Scheme 3. The reaction proceeded firstly via alkylation of the phenoxide by allylic bromide $2,{ }^{20}$ providing $\mathbf{3}$. Oxidative addition of $\mathbf{3}$ to $\operatorname{Pd}(0)$

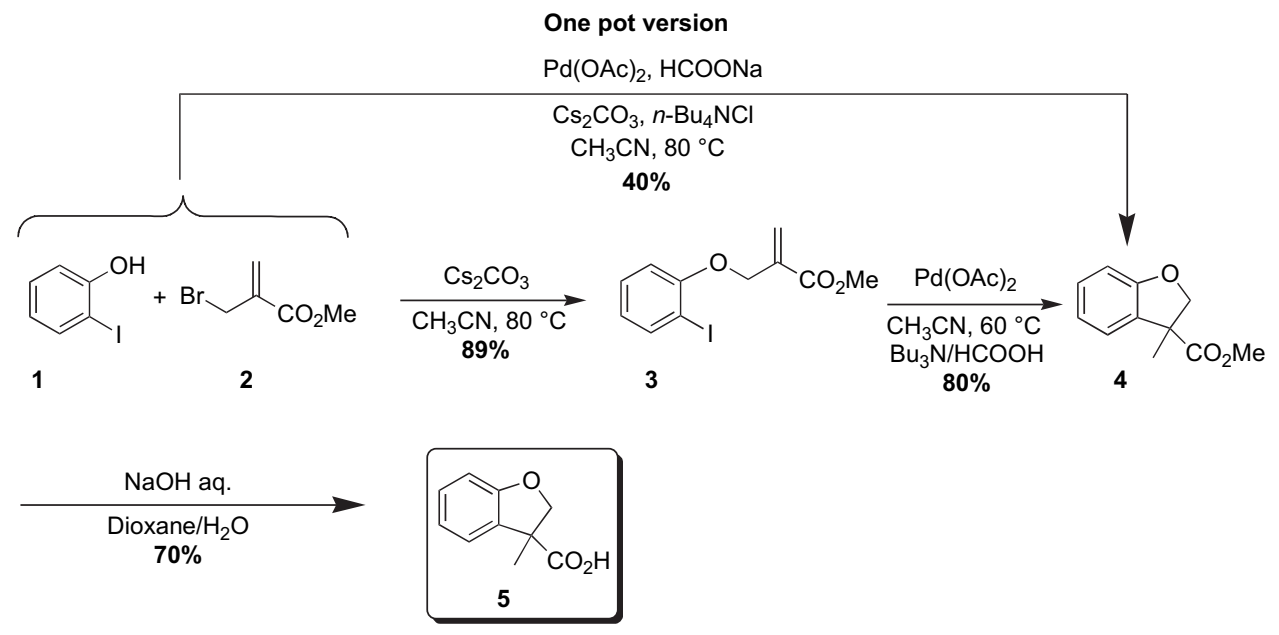

Scheme 2. Synthesis of compound 4 by Pd-catalyzed tandem cyclization/hydride capture in one or two steps. 


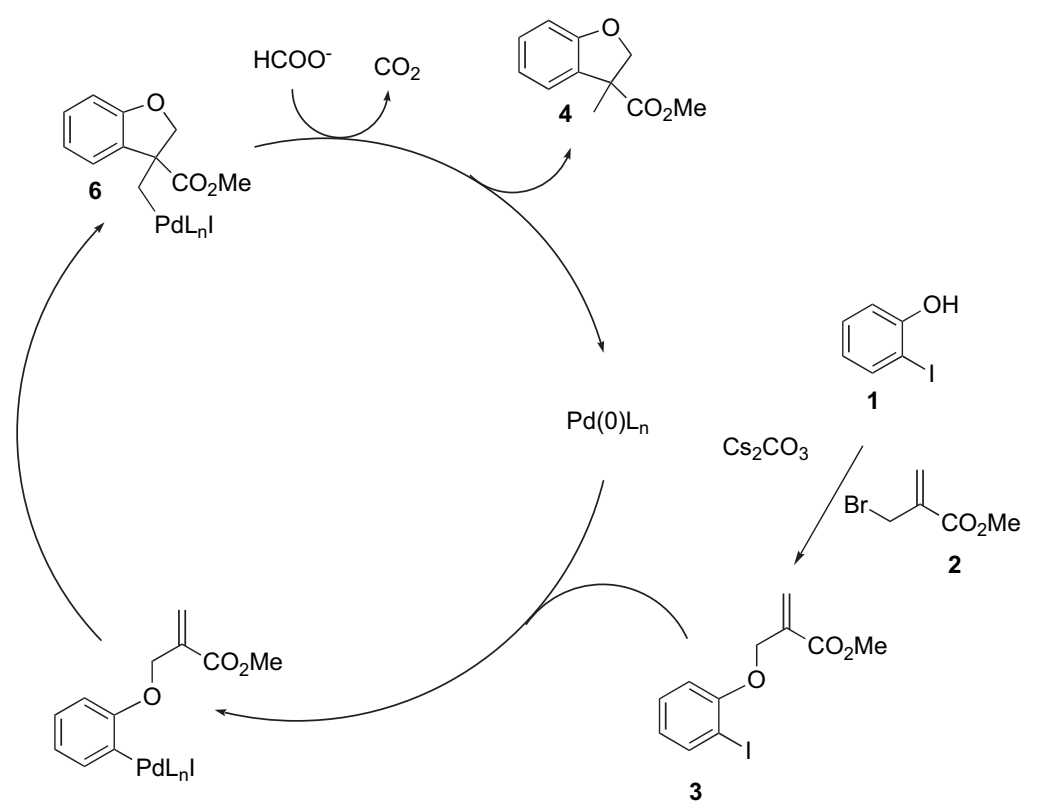

Scheme 3. One-pot version of the tandem alkylation/cyclization/hydride capture.

followed by cyclic carbopalladation of the olefin provided alkylpalladium 6. Hydride trapping, followed by reductive elimination generated the final product 4 and recycled $\operatorname{Pd}(0)$.

Following these results, we introduced an additional source of structural diversity, without changing the starting materials, in order to decorate the basic scaffold with more complicated functionalities than a methyl group. The idea was to trap the intermediate alkylpalladium by various nucleophiles rather than a hydride, which would offer a diversity source. The major challenge was to obtain the correct chronology for the successive steps and avoid direct coupling before the cyclization.

\subsection{Pd-catalyzed tandem cyclization/Heck reaction}

We studied the cyclization step followed by an intermolecular Heck reaction, using methyl acrylate $\mathbf{7}$ as a model substrate, avoiding direct coupling reaction leading to $\mathbf{9}$.

No ideal conditions were found to obtain title compound $\mathbf{8}$ as the sole product of the reaction. In fact, the best results were obtained by using $\mathrm{Et}_{3} \mathrm{~N}$ as a base, DMF as solvent, in the presence of $n-\mathrm{Bu}_{4} \mathrm{NCl}$. Under these reaction conditions, and after $18 \mathrm{~h}$ of reaction, we obtained only a mixture of the desired compounds $8(64 \%)$, the product $\mathbf{9}$, resulting from the direct coupling reaction (25\%), compound 4 , resulting from the hydride capture (10\%) and some iodophenol $\mathbf{1}$, resulting from degradation of $\mathbf{3}$ (Scheme 4).

\subsection{Pd-catalyzed tandem cyclization/cross-coupling}

Different nucleophiles were studied, such as organometallic compounds, to end the synthetic sequence by a cross-coupling reaction in order to improve the structural complexity of the resulting compounds. Since it has been shown in the literature that the cascade could be controlled by the transmetalating reagent, we studied the Stille coupling with tin, known to be slower than with other metals.

Stille coupling: Conditions of introduction of a phenyl group by a Pd-catalyzed tandem cyclization/Stille coupling sequence were studied, involving trimethyl(phenyl)tin $\left(\mathrm{PhSnMe}_{3}\right)($ Scheme 5).

The reaction was performed, in the presence of $n-\mathrm{Bu}_{4} \mathrm{NCl}$, and $\mathrm{Pd}(\mathrm{OAc})_{2}$ in $\mathrm{THF}$ at $60^{\circ} \mathrm{C}$ overnight leading to a mixture of the desired compound 11a (50\%) and of the compound $10(50 \%)$ due to the direct coupling reaction. The 1,3dimethyl-1-2-imidazolidinone (DMI) was added to this system as a co-solvent. In this case, no direct coupling was observed, only the desired compound 11a was obtained in $70 \%$ yield.

Following these promising results, other organometallics were used to introduce a structural diversity, employing diverse terminating cross-coupling reactions. The best results were obtained with the Suzuki coupling.<smiles>C=C(COc1ccccc1I)C(C)=O</smiles>
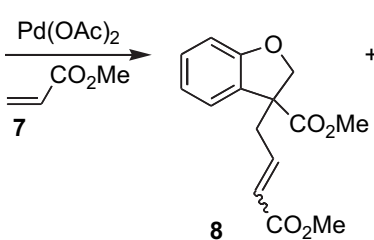<smiles>CC(=O)/C=C/c1ccccc1O</smiles>

9<smiles>COC(C)(OC)C1(C)COc2ccccc21</smiles>

4<smiles>Oc1ccccc1I</smiles>

1 


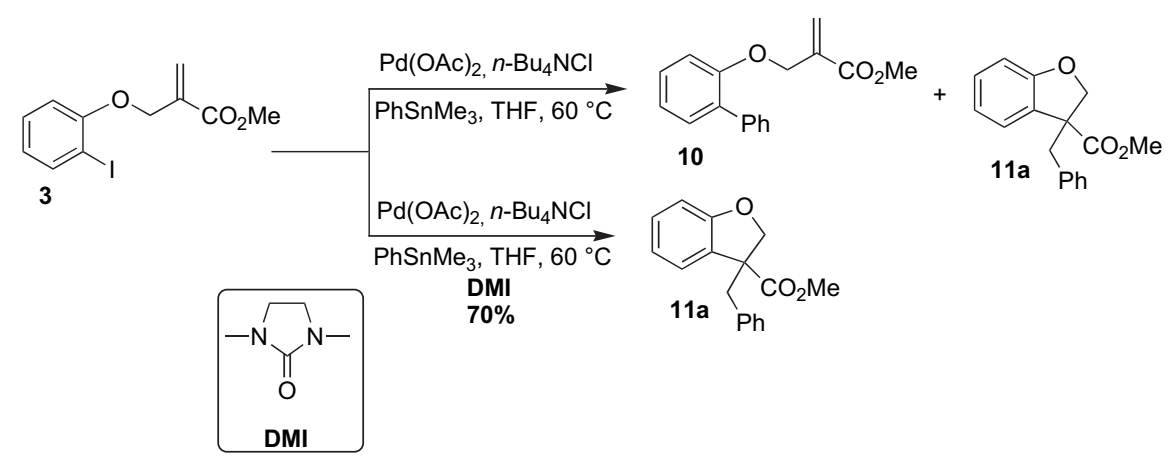

Scheme 5. Pd-catalyzed tandem cyclization/Stille coupling.

Suzuki coupling: The major advantage of this sequence is the existence of a large variety of commercially available boronic acid derivatives, especially aromatic derivatives. To compare the Suzuki coupling with the results previously obtained with the Stille coupling, we used the phenylboronic acid $\left(\mathrm{PhB}(\mathrm{OH})_{2}\right)$. Usual conditions for the Suzuki coupling had to be adapted. Indeed, to perform cyclization/Suzuki coupling most catalytic systems include the presence of phosphines. In our study, the reaction rate was dramatically reduced when triphenylphosphine was used as a ligand. Furthermore, an aqueous medium, which is considered as a standard condition for the Suzuki cross-coupling of arylboronic acids, had to be avoided due to the potential hydrolysis of the methyl ester. Phosphine-free system in the presence of a tretraalkylammonuim salt was efficient in this reaction, previously reported for the Heck reaction ${ }^{21}$ and the Suzuki coupling. ${ }^{22}$ It has been shown that the combination of $\mathrm{Pd}(\mathrm{OAc})_{2}$ with $n-\mathrm{Bu}_{4} \mathrm{NCl}$ in the presence of a base generated colloidal palladium nanoparticles, which are involved in the catalytic cycle. $^{22}$ These conditions allowed us to get the title compound 11a in 54\% yield (Scheme 6).<smiles>[X]C(=O)C(=C)COc1ccccc1I</smiles>

3

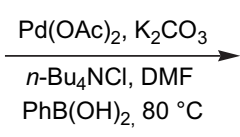

$54 \%$

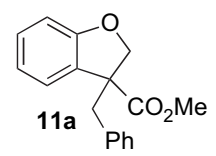

Scheme 6. Pd-catalyzed tandem cyclization/Suzuki coupling using $\mathrm{PhB}(\mathrm{OH})_{2}$.

This result, associated with the very simple reaction conditions, led us to test the parallel synthesis of the dihydrobenzofurans using an organic synthesizer (Argonaut Quest 210 Parallel Synthesizer) and different arylboronic acids (Scheme 7). Table 1 reports the yields of 3,3-disubstituted2,3-dihydrobenzofurans obtained. Electron donating, withdrawing or bulky substituents can be present on the aromatic ring.
Table 1. 3,3-Disubstituted-2,3-dihydrofurans 11

\begin{tabular}{|c|c|c|c|}
\hline Compound & Ar & $\begin{array}{l}\text { Yield of } \\
\mathbf{1 1}(\%)^{\mathrm{a}}\end{array}$ & $\begin{array}{l}\text { Yield of } \\
\mathbf{1 2}(\%)^{\mathrm{a}}\end{array}$ \\
\hline $\mathbf{a}$ & $\mathrm{C}_{6} \mathrm{H}_{5}-$ & 54 & 70 \\
\hline b & 4- $\mathrm{MeO}-\mathrm{C}_{6} \mathrm{H}_{4}-$ & 56 & $-^{\mathrm{b}}$ \\
\hline c & $3-\mathrm{NO}_{2}-\mathrm{C}_{6} \mathrm{H}_{4}-$ & 56 & $-^{\mathrm{b}}$ \\
\hline d & $2-\mathrm{Me}-\mathrm{C}_{6} \mathrm{H}_{4}-$ & 60 & $-^{\mathrm{b}}$ \\
\hline e & $3,4-(\mathrm{OMe})_{2}-\mathrm{C}_{6} \mathrm{H}_{3}-$ & 71 & 64 \\
\hline f & $3,4,5-(\mathrm{OMe})_{3}-\mathrm{C}_{6} \mathrm{H}_{2}-$ & 73 & 71 \\
\hline $\mathbf{g}$ & $2-\mathrm{Cl}-\mathrm{C}_{6} \mathrm{H}_{4}-$ & 66 & 70 \\
\hline h & $3-\mathrm{Cl}-\mathrm{C}_{6} \mathrm{H}_{4}-$ & 82 & 78 \\
\hline i & $4-\mathrm{Cl}-\mathrm{C}_{6} \mathrm{H}_{4}-$ & 68 & 65 \\
\hline j & $3,4-(\mathrm{Cl})_{2}-\mathrm{C}_{6} \mathrm{H}_{3}-$ & 85 & 69 \\
\hline k & $2-\mathrm{CF}_{3}-\mathrm{C}_{6} \mathrm{H}_{4}-$ & 49 & 55 \\
\hline l & $4-\mathrm{CF}_{3} \mathrm{O}-\mathrm{C}_{6} \mathrm{H}_{4}-$ & 66 & 73 \\
\hline m & $4-\mathrm{AcO}-\mathrm{C}_{6} \mathrm{H}_{4}-$ & 73 & 71 \\
\hline $\mathbf{n}$ & $4-\mathrm{CH}_{3} \mathrm{O}\left(\mathrm{CH}_{2}\right)_{2} \mathrm{OCH}_{2} \mathrm{O}-\mathrm{C}_{6} \mathrm{H}_{4}-$ & 79 & 91 \\
\hline $\mathbf{0}$ & $4-\mathrm{CH}_{2}=\mathrm{CH}-\mathrm{C}_{6} \mathrm{H}_{4-}$ & 53 & 95 \\
\hline $\mathbf{p}$ & & 78 & 50 \\
\hline $\mathbf{q}$ & & 81 & 88 \\
\hline $\mathbf{r}$ & & 71 & $-\mathrm{b}$ \\
\hline
\end{tabular}

a Yield of isolated compounds.

b The hydrolysis was not performed.

Thus, 18 products were obtained using this methodology, in moderate to good yields. Most of them were converted into their corresponding carboxylic acid derivatives 12a and $12 \mathbf{e}-\mathbf{q}$, using the conditions described for the synthesis of 5 . $^{23}$

This sequence was performed in a one-pot version, starting from $\mathbf{1}$ and $\mathbf{2}$, with different arylboronic acids (Scheme 8).

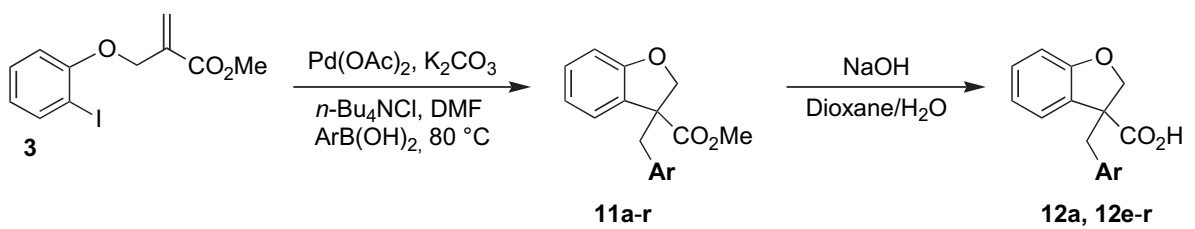

Scheme 7. Pd-catalyzed tandem cyclization/Suzuki coupling using various arylboronic acids followed by a saponification reaction. 


$$
\text { (11a-d, 11r }
$$

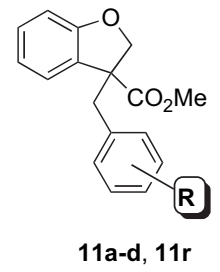

Scheme 8. One-pot allylation/cyclization/Suzuki coupling cascade.

In the catalytic cycle, the formation of the alkylpalladium 6 was followed by a transmetallation step with phenylboronate (from the reaction of $\mathrm{PhB}(\mathrm{OH})_{2}$ with the base and/or anions present in the reaction medium). Finally, the reductive elimination generates the title compound 11a and recycles $\operatorname{Pd}(0)$ (Scheme 9).

\section{Conclusion}

We have developed a very simple and an efficient method for the synthesis of a wide range of functionalized 3,3-disubstituted-2,3-dihydrobenzofurans, from commercially available 2-iodophenol, and methyl bromomethylacrylate via Pd-catalyzed tandem cyclization/Suzuki cross-coupling. Those conditions could be directly applied to automated synthesis leading to libraries of functionalized heterocyclic building blocks. This strategy will now be extended to more functionalized phenols and other 1,1-disubstituted alkenes, to introduce additional diversity and structural complexity. Finally, an asymmetric version of this reaction is currently underway, in order to control the configuration of the newly created stereogenic center.

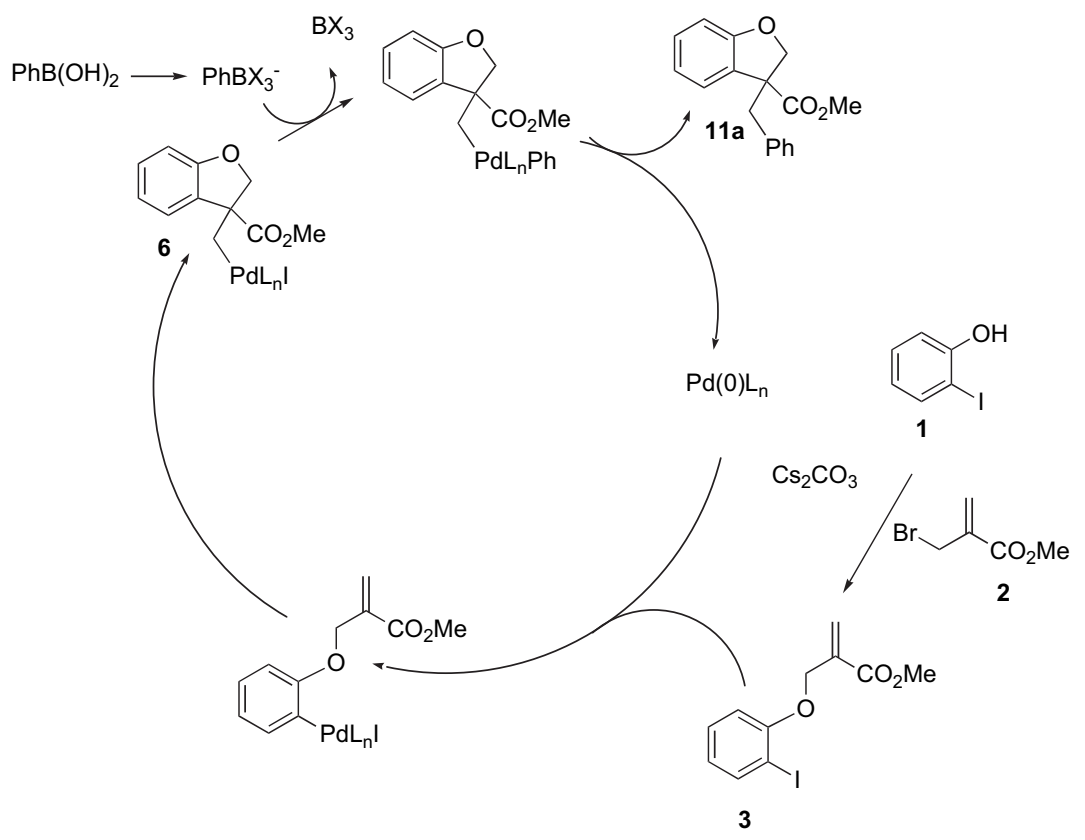

Scheme 9. Cascade allylation/cyclization/Suzuki coupling.

To our knowledge, only few examples of allylations combined with a $\mathrm{Pd}$-catalyzed process are described in the literature. ${ }^{18,19,24-28}$

Table 2 reports the yields of 3,3-disubstituted-2,3-dihydrobenzofurans obtained from five different arylboronic acids, $\operatorname{ArB}(\mathrm{OH})_{2}$. As observed before, electron donating and withdrawing substituents can be present on the aromatic ring. However, substitution at the ortho position led to lower yields.

Table 2. One-pot synthesis of 3,3-disubstituted-2,3-dihydrofurans

\begin{tabular}{lll}
\hline $\mathbf{1 1}$ & $\mathrm{R}$ & Yield $(\%)^{\mathrm{a}}$ \\
\hline $\mathbf{a}$ & $\mathrm{H}$ & $45^{\mathrm{b}}$ \\
$\mathbf{b}$ & $4-\mathrm{OMe}$ & 50 \\
c & $3-\mathrm{NO}_{2}$ & 40 \\
d & $2-\mathrm{Me}$ & 28 \\
$\mathbf{r}$ & $4-\mathrm{Ph}$ & 57
\end{tabular}

a Yield of isolated compounds.

b Compound 11a was obtained as the sole product (74\% NMR yield).

\section{Experimental section}

\subsection{General}

All reagents were commercially available and used without purification. IR spectra were recorded on Perkin Elmer FT Paragon 1000 spectrometer. ${ }^{1} \mathrm{H}$ and ${ }^{13} \mathrm{C}$ NMR analyses were performed with a Brüker AC $400 \mathrm{MHz}$ and $200 \mathrm{MHz}$. IR spectra were recorded on Perkin Elmer FT Paragon 1000 spectrometer. Mass spectra were recorded on JEOL JSM DX300-SX 102 spectrometer, with 3-nitrobenzyl alcohol (NBA) or a mixture glycerol/thioglycerol (50/50, v/v) (GT) as matrix.

4.1.1. 2-(3-Methoxycarbonylallyloxyl)-iodobenzene (3). To a solution of methyl-2-bromomethacrylate 2 (3.52 g, $16.67 \mathrm{mmol})$ in $\mathrm{CH}_{3} \mathrm{CN}(160 \mathrm{~mL})$ were added $\mathrm{Cs}_{2} \mathrm{CO}_{3}$ (4.47 g, $13.36 \mathrm{mmol})$ and 2-iodophenol 1 (2.1 g, $9.54 \mathrm{mmol})$. The resulting mixture was stirred for $5 \mathrm{~h}$ at $80{ }^{\circ} \mathrm{C}$, cooled to room temperature, diluted with $\mathrm{Et}_{2} \mathrm{O}$, and filtered over Celite. The organic layer was washed with 
brine, dried over $\mathrm{MgSO}_{4}$, filtered, and concentrated. Column chromatography (silica gel, hexane $/ \mathrm{CH}_{2} \mathrm{Cl}_{2}$ : 1/1) afforded $2.71 \mathrm{~g}(89 \%)$ of $3:{ }^{1} \mathrm{H}$ NMR $\left(250 \mathrm{MHz}, \mathrm{CDCl}_{3}\right) \delta 3.78(\mathrm{~s}$, $3 \mathrm{H}), 4.76(\mathrm{~d}, 2 \mathrm{H}, J=1.7 \mathrm{~Hz}), 6.23(\mathrm{~d}, 1 \mathrm{H}, J=1.2 \mathrm{~Hz}), 6.42$ $(\mathrm{d}, 1 \mathrm{H}, J=1.3 \mathrm{~Hz}), 6.70(\mathrm{td}, 1 \mathrm{H}, J=7.6 \mathrm{~Hz}, J=1.1 \mathrm{~Hz})$, $6.80(\mathrm{~d}, \quad 1 \mathrm{H}, \quad J=8.2 \mathrm{~Hz}), \quad 7.26(\mathrm{td}, \quad 1 \mathrm{H}, \quad J=8.6 \mathrm{~Hz}$, $J=1.5 \mathrm{~Hz}), 7.74(\mathrm{dd}, 1 \mathrm{H}, J=7.8 \mathrm{~Hz}, J=1.5 \mathrm{~Hz}) ;{ }^{13} \mathrm{C} \mathrm{NMR}$ $\left(100 \mathrm{MHz}, \mathrm{CDCl}_{3}\right) \delta 52.46,67.30,86.87,112.83,123.41$, $127.26,129.95,135.43,139.9,157.12,166.19$; IR (film) $\nu$ 3024, 3000, 2949, 2844, 1717, 1636.5, 1581, 1475, 1438, $1396,1313,1278,1250,1195,1155,1121,1056,1036$, 1018, 956, 868, 817, 748, $642 \mathrm{~cm}^{-1}$; MS $\left(\mathrm{FAB}^{+}, \mathrm{GT}\right)$ $m / z=319\left(\mathrm{MH}^{+}\right), 233,149,131$; HRMS for $\mathrm{C}_{11} \mathrm{H}_{12} \mathrm{O}_{3} \mathrm{I}$ $\left(\mathrm{MH}^{+}\right)$: calcd 318.9831 found 318.9843 .

4.1.2. 3-Methyl-3-methoxycarbonyl-2,3-dihydrobenzofuran (4). To a solution of $\mathrm{Bu}_{3} \mathrm{~N}(2.77 \mathrm{~mL}, 11.62 \mathrm{mmol})$ in acetonitrile $(60 \mathrm{~mL})$ was added $\mathrm{HCOOH}(0.219 \mathrm{~mL}$, $5.81 \mathrm{mmol}$ ). The resulting mixture was stirred for $10 \mathrm{~min}$ at room temperature. To this mixture were then added a solution of 3 (1.68 g, $5.28 \mathrm{mmol})$ in $\mathrm{CH}_{3} \mathrm{CN}(10 \mathrm{~mL})$, and a solution of $\mathrm{Pd}(\mathrm{OAc})_{2}(118.5 \mathrm{mg}, 0.528 \mathrm{mmol})$ in $\mathrm{CH}_{3} \mathrm{CN}$ $(2 \mathrm{~mL})$. The resulting mixture was stirred for $17 \mathrm{~h}$ at $60{ }^{\circ} \mathrm{C}$, cooled to room temperature and concentrated. The residue was dissolved in $\mathrm{Et}_{2} \mathrm{O}$, and the resulting organic layer was washed with brine, dried over $\mathrm{MgSO}_{4}$, filtered, and concentrated. The residue was dissolved finally in hexane and filtered over alumina and concentrated affording $811 \mathrm{mg}(80 \%)$ of 4 .

One-pot version: To a solution of $2(58.3 \mathrm{mg}, 0.326 \mathrm{mmol})$ in $\mathrm{CH}_{3} \mathrm{CN}(5 \mathrm{~mL})$ were added $\mathrm{Cs}_{2} \mathrm{CO}_{3} \quad(318.8 \mathrm{mg}$, $0.979 \mathrm{mmol}), \quad 1 \quad(51.2 \mathrm{mg}, \quad 0.233 \mathrm{mmol}), \quad \mathrm{HCOONa}$ (21.9 mg, $0.326 \mathrm{mmol}), \mathrm{Pd}(\mathrm{OAc})_{2}(5.23 \mathrm{mg}, 0.023 \mathrm{mmol})$, and $n-\mathrm{Bu}_{4} \mathrm{NCl}(77.4 \mathrm{mg}, 0.280 \mathrm{mmol})$. The resulting mixture was stirred for $17 \mathrm{~h}$ at $80{ }^{\circ} \mathrm{C}$, cooled to room temperature and concentrated. The residue was dissolved in $\mathrm{Et}_{2} \mathrm{O}$, and the resulting organic layer was washed with brine, dried over $\mathrm{MgSO}_{4}$, filtered, and concentrated. The residue was dissolved in hexane and filtered over alumina and concentrated affording $18 \mathrm{mg}(40 \%)$ of $4:{ }^{1} \mathrm{H}$ NMR $\left(250 \mathrm{MHz}, \mathrm{CDCl}_{3}\right)$ $\delta 1.57(\mathrm{~s}, 3 \mathrm{H}), 3.69(\mathrm{~s}, 3 \mathrm{H}), 4.21(\mathrm{~d}, 1 \mathrm{H}, J=9 \mathrm{~Hz}), 5.02(\mathrm{~d}$, $1 \mathrm{H}, J=9 \mathrm{~Hz}), 6.76-6.89(\mathrm{~m}, 2 \mathrm{H}), 7.14(\mathrm{td}, 1 \mathrm{H}, J=7.7 \mathrm{~Hz}$, $J=1.4 \mathrm{~Hz}), 7.28(\mathrm{dd}, 1 \mathrm{H}, J=7.5 \mathrm{~Hz}, J=1.3 \mathrm{~Hz}) ;{ }^{13} \mathrm{C} \mathrm{NMR}$ $\left(100 \mathrm{MHz}, \mathrm{CDCl}_{3}\right) \delta 24.95,52.71,53.12,80.38,110.42$, $121.22,124.68,129.75,130.40,159.79,174.62$; IR (film) $\nu$ 3030, 2952, 2896, 2849, 2796, 1732, 1597, 1482, 1462, 1222, 1137, 1107, 1068, 1017, $987 \mathrm{~cm}^{-1}$; $\mathrm{MS}\left(\mathrm{FAB}^{+}\right.$, NBA) $m / z=192\left(\mathrm{M}^{+}\right), 149,133\left(\mathrm{M}^{+}-\mathrm{CO}_{2} \mathrm{Me}\right), 97,81,72$, 55, 43, 29; HRMS for $\mathrm{C}_{11} \mathrm{H}_{12} \mathrm{O}_{3}\left(\mathrm{M}^{+}\right)$: calcd 192.0786 found 192.0787 .

\subsubsection{3-Methyl-2,3-dihydrobenzofuran-3-carboxylic} acid (5). To a solution of $4(1.15 \mathrm{~g}, 5.99 \mathrm{mmol})$ in a mixture of dioxane/ $\mathrm{H}_{2} \mathrm{O}(9 / 1)(50 \mathrm{~mL})$ was added aqueous solution of $\mathrm{NaOH}$ (2 M) (13.5 mL, $26.95 \mathrm{mmol})$. The resulting mixture was stirred for $4 \mathrm{~h}$ at room temperature and concentrated. The residue was dissolved in $\mathrm{H}_{2} \mathrm{O}$, and the aqueous layer was extracted three times with $\mathrm{Et}_{2} \mathrm{O}$, acidified by adding $\mathrm{HCl}(1 \mathrm{~N})$ until $\mathrm{pH}=1-3$ and extracted three times with $\mathrm{Et}_{2} \mathrm{O}$. The combined organic layers were washed with brine, dried over $\mathrm{MgSO}_{4}$, filtered, and concentrated affording $746 \mathrm{mg}(70 \%)$ of $5:{ }^{1} \mathrm{H} \mathrm{NMR}\left(250 \mathrm{MHz}, \mathrm{CDCl}_{3}\right) \delta 1.60(\mathrm{~s}$,
$3 \mathrm{H}), 4.21(\mathrm{~d}, 1 \mathrm{H}, J=9.2 \mathrm{~Hz}), 5.02(\mathrm{~d}, 1 \mathrm{H}, J=9.2 \mathrm{~Hz}), 6.78$ $(\mathrm{d}, 1 \mathrm{H}, J=8.1 \mathrm{~Hz}), 6.87(\mathrm{td}, 1 \mathrm{H}, J=7.5 \mathrm{~Hz}, J=0.8 \mathrm{~Hz})$, $7.16(\mathrm{td}, \quad 1 \mathrm{H}, \quad J=7.7 \mathrm{~Hz}, J=1.3 \mathrm{~Hz}), 7.31 \quad(\mathrm{dd}, 1 \mathrm{H}$, $J=7.5 \mathrm{~Hz}, \quad J=1.2 \mathrm{~Hz}) ;{ }^{13} \mathrm{C} \quad \mathrm{NMR} \quad\left(100 \mathrm{MHz}, \mathrm{CDCl}_{3}\right)$ $\delta$ 24.54, 52.60, 79.98, 110.54, 121.36, 124.76, 129.68, 130.05, 159.80, 180.37; IR (film) $\nu$ 3084, 3020, 2973, 2929, 2849, 1704, 1597, 1482, 1462, 1410, 1296, 1238, 1177, 1154, 1068, 1017, 988, 833, 752, 685, $622 \mathrm{~cm}^{-1}$; $\mathrm{MS}\left(\mathrm{FAB}^{+}, \mathrm{NBA}\right) m / z=178\left(\mathrm{M}^{+}\right), 133\left(\mathrm{M}^{+}-\mathrm{CO}_{2} \mathrm{H}\right), 105$, 89, 77; HRMS for $\mathrm{C}_{10} \mathrm{H}_{10} \mathrm{O}_{3}\left(\mathrm{M}^{+}\right)$: calcd 178.0630 found 178.0624 .

4.1.4. 3-Methylacrylate-3-methoxycarbonyl-2,3-dihydrobenzofuran (8). To a solution of 3 (60.3 mg, $0.19 \mathrm{mmol})$ in $\mathrm{DMF}(4 \mathrm{~mL})$ were added $\mathrm{Et}_{3} \mathrm{~N}(53 \mu \mathrm{L}$, $0.38 \mathrm{mmol}), n-\mathrm{Bu}_{4} \mathrm{NCl}(63.3 \mathrm{mg}, 0.228 \mathrm{mmol})$, a solution of $\mathrm{Pd}(\mathrm{OAc})_{2}(4.4 \mathrm{mg}, 0.019 \mathrm{mmol})$ in $\mathrm{DMF}(1 \mathrm{~mL})$, and methyl acrylate $7(18.9 \mu \mathrm{L}, 0.209 \mathrm{mmol})$. The resulting mixture was stirred for $16 \mathrm{~h}$ at $80{ }^{\circ} \mathrm{C}$, cooled to room temperature, diluted with $\mathrm{Et}_{2} \mathrm{O}$, and filtered over Celite. This organic layer was washed with brine, dried over $\mathrm{MgSO}_{4}$, filtered, and concentrated affording a mixture of $\mathbf{8}$, as a major compound ( $64 \%$ by NMR), 9, 4, and $\mathbf{1}$.

4.1.5. 3-Benzyl-3-methoxycarbonyl-2,3-dihydrobenzofuran (11a). Stille conditions: To a solution of $\mathbf{3}(200.4 \mathrm{mg}$, $0.629 \mathrm{mmol})$ and DMI $(0.240 \mathrm{~mL}, 2.2 \mathrm{mmol})$ in THF $(12 \mathrm{~mL})$ were added $n$ - $\mathrm{Bu}_{4} \mathrm{NCl}(209.75 \mathrm{mg}, 0.755 \mathrm{mmol})$, a solution of $\mathrm{Pd}(\mathrm{OAc})_{2}(14.12 \mathrm{mg}, 0.063 \mathrm{mmol})$ in $\mathrm{THF}$ $(1 \mathrm{~mL})$, and $\mathrm{Me}_{3} \mathrm{PhSn}(0.137 \mathrm{~mL}, 0.755 \mathrm{mmol})$. The resulting mixture was stirred for $17 \mathrm{~h}$ at $60{ }^{\circ} \mathrm{C}$, cooled to room temperature, diluted with $\mathrm{Et}_{2} \mathrm{O}$, and filtered over Celite. This organic layer was washed with brine, dried over $\mathrm{MgSO}_{4}$, filtered, and concentrated. Column chromatography (silica gel, hexane/ $\left.\mathrm{CH}_{2} \mathrm{Cl}_{2}: 1 / 1\right)$ afforded $118 \mathrm{mg}(70 \%)$ of 11 .

Suzuki conditions: To a solution of 3 (106.6 mg, $0.335 \mathrm{mmol})$ in DMF (6 mL) were added $\mathrm{K}_{2} \mathrm{CO}_{3}(92.6 \mathrm{mg}$, $0.670 \mathrm{mmol}), n-\mathrm{Bu}_{4} \mathrm{NCl}(111.7 \mathrm{mg}, 0.402 \mathrm{mmol})$, a solution of $\mathrm{Pd}(\mathrm{OAc})_{2}(7.5 \mathrm{mg}, 0.0335 \mathrm{mmol})$ in DMF $(1 \mathrm{~mL})$, and a solution of $\mathrm{Ph}(\mathrm{BOH})_{2}(44.9 \mathrm{mg}, 0.368 \mathrm{mmol})$ in $\mathrm{DMF}$ $(2 \mathrm{~mL})$. The resulting mixture was stirred for $15 \mathrm{~h}$ at $80{ }^{\circ} \mathrm{C}$, cooled to room temperature filtered over Celite and concentrated. Column chromatography (silica gel, hexane/ $\mathrm{CH}_{2} \mathrm{Cl}_{2}$ : 1/1) afforded $48.5 \mathrm{mg}(54 \%)$ of $11 \mathrm{a}$.

One-pot version: To a solution of $2(48.9 \mathrm{mg}, 0.273 \mathrm{mmol})$ in DMF $(3 \mathrm{~mL})$ were added $\mathrm{K}_{2} \mathrm{CO}_{3}(110.15 \mathrm{mg}, 0.955$ $\mathrm{mmol}), \quad 1 \quad(50.1 \mathrm{mg}, \quad 0.228 \mathrm{mmol}), \quad n-\mathrm{Bu}_{4} \mathrm{NCl}$ (76 mg, $0.274 \mathrm{mmol})$, a solution of $\mathrm{Pd}(\mathrm{OAc})_{2}(5.12 \mathrm{mg}, 0.0273$ $\mathrm{mmol})$ in $\mathrm{DMF}(1 \mathrm{~mL})$, and $\mathrm{Ph}(\mathrm{BOH})_{2} \quad(30.54 \mathrm{mg}$, $0.3 \mathrm{mmol})$. The resulting mixture was stirred for $15 \mathrm{~h}$ at $80{ }^{\circ} \mathrm{C}$, cooled to room temperature filtered over Celite and concentrated. Column chromatography (silica gel, hexane/ $\mathrm{CH}_{2} \mathrm{Cl}_{2}$ : 1/1) afforded $27.5 \mathrm{mg}(45 \%)$ of 11a: ${ }^{1} \mathrm{H} \mathrm{NMR}$ $\left(250 \mathrm{MHz}, \mathrm{CDCl}_{3}\right) \delta 3.12(\mathrm{~d}, 1 \mathrm{H}, J=13.7 \mathrm{~Hz}), 3.50(\mathrm{~d}$, $1 \mathrm{H}, J=13.7 \mathrm{~Hz}), 3.76(\mathrm{~s}, 3 \mathrm{H}), 4.53(\mathrm{~d}, 1 \mathrm{H}, J=9.5 \mathrm{~Hz})$, $4.91(\mathrm{~d}, 1 \mathrm{H}, J=9.5 \mathrm{~Hz}), 6.81(\mathrm{~d}, 1 \mathrm{H}, J=8 \mathrm{~Hz}), 6.94(\mathrm{td}$, $1 \mathrm{H}, J=7.5 \mathrm{~Hz}, J=0.9 \mathrm{~Hz}), 7.03-7.07(\mathrm{~m}, 2 \mathrm{H}), 7.19-7.30$ $(\mathrm{m}, 4 \mathrm{H}), 7.41(\mathrm{dd}, 1 \mathrm{H}, J=7.5 \mathrm{~Hz}, J=1.2 \mathrm{~Hz}) ;{ }^{13} \mathrm{C} \mathrm{NMR}$ $\left(100 \mathrm{MHz}, \mathrm{CDCl}_{3}\right) \delta 44.46,52.93,58.10,77.01,110.48$, 121.09, 125.52, 127.51, 128.84, 129.99, 130.01, 136.59, 
159.94, 173.28; IR (film) $\nu$ 3030, 2953, 2923, 2849, 1733, 1596, 1480, 1459, 1436, 1315, 1293, 1226, 1098, 1088, $1022,979,877,834,798,753,701 \mathrm{~cm}^{-1}$; MS $\left(\mathrm{FAB}^{+}\right.$, NBA) $\quad m / z=268 \quad\left(\mathrm{M}^{+}\right), \quad 209 \quad\left(\mathrm{M}^{+}-\mathrm{CO}_{2} \mathrm{Me}\right), \quad 177$ $\left(\mathrm{M}^{+}-\mathrm{CH}_{2} \mathrm{Ph}\right), 149,105,91,69,55,43,41,29$; HRMS for $\mathrm{C}_{17} \mathrm{H}_{16} \mathrm{O}_{3}\left(\mathrm{M}^{+}\right)$: calcd 268.1099 found 268.1081.

4.1.6. 3-Benzyl-2,3-dihydrobenzofuran-3-carboxylic acid (12a). To a solution of $11 \mathrm{a}(28 \mathrm{mg}, 0.104 \mathrm{mmol})$ in a mixture of dioxane/ $\mathrm{H}_{2} \mathrm{O}(9 / 1)(10 \mathrm{~mL})$ was added aqueous solution of $\mathrm{NaOH}(2 \mathrm{M})(0.235 \mathrm{~mL}, 0.470 \mathrm{mmol})$. The resulting mixture was stirred for $4 \mathrm{~h}$ at room temperature and concentrated. The residue was dissolved in $\mathrm{H}_{2} \mathrm{O}$, and the aqueous layer was extracted three times with $\mathrm{Et}_{2} \mathrm{O}$, acidified with $1 \mathrm{~N} \mathrm{HCl}$ until $\mathrm{pH}=1-3$ and extracted three times with $\mathrm{Et}_{2} \mathrm{O}$. The combined organic layers were washed with brine, dried over $\mathrm{MgSO}_{4}$, filtered, and concentrated affording $18.5 \mathrm{mg}(70 \%)$ of 10a: ${ }^{1} \mathrm{H}$ NMR $\left(250 \mathrm{MHz}, \mathrm{CDCl}_{3}\right) \delta 3.09$ $(\mathrm{d}, 1 \mathrm{H}, J=13.8 \mathrm{~Hz}), 3.47(\mathrm{~d}, 1 \mathrm{H}, J=13.8 \mathrm{~Hz}), 4.46(\mathrm{~d}, 1 \mathrm{H}$, $J=9.6 \mathrm{~Hz}), 4.84(\mathrm{~d}, 1 \mathrm{H}, J=9.6 \mathrm{~Hz}), 6.75(\mathrm{~d}, 1 \mathrm{H}, J=8 \mathrm{~Hz})$, $6.90(\mathrm{t}, 1 \mathrm{H}, J=7.4 \mathrm{~Hz}), 7.01-7.05(\mathrm{~m}, 2 \mathrm{H}), 7.14-7.21(\mathrm{~m}$, $4 \mathrm{H}), 7.38(\mathrm{~d}, 1 \mathrm{H}, J=7.6 \mathrm{~Hz}) ;{ }^{13} \mathrm{C}$ NMR $\left(100 \mathrm{MHz}, \mathrm{CDCl}_{3}\right)$ $\delta 44.00,57.95,76.64,110.59,121.24,125.51,127.64$, $128.24,128.93,130.04,130.31,136.28,159.97,178.29$; IR (film) $\nu$ 3082, 3030, 2959, 2926, 2850, 1702, 1596, $1480,1460,1410,1315,1291,1276,1239,1099,1088$, 1022, 973, 834, 751, $701 \mathrm{~cm}^{-1}$; MS (FAB ${ }^{-}, \mathrm{NBA}$ ) $m / z=253(\mathrm{M} \cdot-\mathrm{H}), 209\left(\mathrm{M} \cdot-\mathrm{CO}_{2} \mathrm{H}\right), 46$; HRMS for $\mathrm{C}_{16} \mathrm{H}_{13} \mathrm{O}_{3}(\mathrm{M} \cdot-\mathrm{H})$ : calcd 253.0865 found 253.0860.

4.1.7. 3-(4-Methoxybenzyl)-3-methoxycarbonyl-2,3-dihydrobenzofuran (11b). Synthesized according to the procedure described for the preparation of 11a, using 4methoxyphenylboronic acid, followed by column chromatography (silica gel, hexane/ $\left.\mathrm{CH}_{2} \mathrm{Cl}_{2}: 2 / 3\right)$ afforded $\mathbf{1 1 b}(56 \%$ and $50 \%$ one-pot version): ${ }^{1} \mathrm{H}$ NMR $\left(250 \mathrm{MHz}, \mathrm{CDCl}_{3}\right)$ $\delta 3.00(\mathrm{~d}, 1 \mathrm{H}, J=13.8 \mathrm{~Hz}), 3.36(\mathrm{~d}, 1 \mathrm{H}, J=13.8 \mathrm{~Hz}), 3.70$ $(\mathrm{s}, 3 \mathrm{H}), 3.73(\mathrm{~s}, 3 \mathrm{H}), 4.45(\mathrm{~d}, 1 \mathrm{H}, J=9.5 \mathrm{~Hz}), 4.83(\mathrm{~d}, 1 \mathrm{H}$, $J=9.5 \mathrm{~Hz}), 6.74(\mathrm{~d}, 3 \mathrm{H}, J=8.6 \mathrm{~Hz}), 6.84-7.00(\mathrm{~m}, 3 \mathrm{H})$, $7.15(\mathrm{td}, 1 \mathrm{H}, J=7.8 \mathrm{~Hz}, J=1.3 \mathrm{~Hz}), 7.34(\mathrm{dd}, 1 \mathrm{H}$, $J=7.5 \mathrm{~Hz}, \quad J=1.2 \mathrm{~Hz}) ;{ }^{13} \mathrm{C} \quad \mathrm{NMR} \quad\left(100 \mathrm{MHz}, \mathrm{CDCl}_{3}\right)$ $\delta \quad 43.68,52.90,55.59,58.26,77.00,110.44,114.21$, $121.04,125.55,128.58,128.81,129.94,131.02,159.09$, 159.95, 173.37; IR (film) $\nu$ 3065-2998, 2952, 2924, 2849, $1732,1610,1596,1583,1513,1480,1461,1440,1291$, 1274, 1247, 1179, 1114, 1097, 1035, 980, 936, 835, 793, $755 \mathrm{~cm}^{-1}$; MS $\left(\mathrm{FAB}^{+}, \mathrm{NBA}\right) \mathrm{m} / z=299\left(\mathrm{MH}^{+}\right), 239$ $\left(\mathrm{M}^{+}-\mathrm{CO}_{2} \mathrm{Me}\right), 214,121,177\left(\mathrm{M}^{+}-\mathrm{CH}_{2} \mathrm{Ar}\right), 69,57,41$, 29; HRMS for $\mathrm{C}_{18} \mathrm{H}_{19} \mathrm{O}_{4}\left(\mathrm{MH}^{+}\right)$: calcd 299.1283 found 299.1283.

4.1.8. 3-(3-Nitrobenzyl)-3-methoxycarbonyl-2,3-dihydrobenzofuran (11c). Synthesized according to the procedure described for the preparation of 11a, using 3nitrophenylboronic acid, followed by column chromatography (silica gel, hexane/ $\mathrm{CH}_{2} \mathrm{Cl}_{2}: 2 / 3$ ) afforded 11c $(56 \%$ and $40 \%$ one-pot version): ${ }^{1} \mathrm{H}$ NMR $\left(250 \mathrm{MHz}, \mathrm{CDCl}_{3}\right)$ $\delta 3.26(\mathrm{~d}, 1 \mathrm{H}, J=13.6 \mathrm{~Hz}), 3.48(\mathrm{~d}, 1 \mathrm{H}, J=13.6 \mathrm{~Hz}), 3.80$ $(\mathrm{s}, 3 \mathrm{H}), 4.48(\mathrm{~d}, 1 \mathrm{H}, J=9.6 \mathrm{~Hz}), 4.89(\mathrm{~d}, 1 \mathrm{H}, J=9.6 \mathrm{~Hz})$, $6.77(\mathrm{~d}, 1 \mathrm{H}, J=8 \mathrm{~Hz}), 6.97(\mathrm{t}, 1 \mathrm{H}, J=7.5 \mathrm{~Hz}), 7.19-7.45$ $(\mathrm{m}, 4 \mathrm{H}), 7.88(\mathrm{br} \mathrm{s}, 1 \mathrm{H}), 8.11(\mathrm{~d}, 1 \mathrm{H}, J=8.2 \mathrm{~Hz}) ;{ }^{13} \mathrm{C}$ NMR $\left(100 \mathrm{MHz}, \mathrm{CDCl}_{3}\right) \delta 43.83,53.24,57.86,76.84$, $110.69,121.36,122.67,124.96,125.36,127.82,129.63$,
130.45, 136.27, 138.47, 148.52, 159.92, 172.80; IR (film) $\nu$ 3056, 2955, 2927, 2850, 1732, 1583, 1531, 1481, 1461, $1436,1353,1266,1230,1101,1024,986,894,806$, $737 \mathrm{~cm}^{-1} ; \quad$ MS $\left(\mathrm{FAB}^{+}, \quad \mathrm{GT}\right) \quad m / z=314 \quad\left(\mathrm{MH}^{+}\right), 254$ $\left(\mathrm{M}^{+}-\mathrm{CO}_{2} \mathrm{Me}\right), 242,177\left(\mathrm{M}^{+}-\mathrm{CH}_{2} \mathrm{Ar}\right), 147,136,110$; HRMS for $\mathrm{C}_{17} \mathrm{H}_{16} \mathrm{O}_{5} \mathrm{~N}\left(\mathrm{MH}^{+}\right)$: calcd 314.1028 found 314.1039 .

4.1.9. 3-(2-Methylbenzyl)-3-methoxycarbonyl-2,3-dihydrobenzofuran (11d). Synthesized according to the procedure described for the preparation of 11a, using 2methylphenylboronic acid, followed by column chromatography (silica gel, hexane/ $\mathrm{CH}_{2} \mathrm{Cl}_{2}: 1 / 1$ ) afforded 11d $(60 \%$ and $28 \%$ one-pot version): ${ }^{1} \mathrm{H}$ NMR $\left(250 \mathrm{MHz}, \mathrm{CDCl}_{3}\right)$ $\delta 2.05(\mathrm{~s}, 3 \mathrm{H}), 3.13(\mathrm{~d}, 1 \mathrm{H}, J=14.7 \mathrm{~Hz}), 3.45(\mathrm{~d}, 1 \mathrm{H}$, $J=14.7 \mathrm{~Hz}), 3.71(\mathrm{~s}, 3 \mathrm{H}), 4.38(\mathrm{~d}, 1 \mathrm{H}, J=9.4 \mathrm{~Hz}), 4.92(\mathrm{~d}$, $1 \mathrm{H}, J=9.4 \mathrm{~Hz}), 6.77(\mathrm{~d}, 1 \mathrm{H}, J=8 \mathrm{~Hz}), 6.81-6.88(\mathrm{~m}, 2 \mathrm{H})$, $7.03-7.11(\mathrm{~m}, 2 \mathrm{H}), 7.15(\mathrm{dd}, 1 \mathrm{H}, J=7.8 \mathrm{~Hz}, J=1.4 \mathrm{~Hz})$, 7.19-7.23 (m, 2H); ${ }^{13} \mathrm{C}$ NMR $\left(100 \mathrm{MHz}, \mathrm{CDCl}_{3}\right) \delta 20.10$, $40.76,53.02,57.63,77.62,110.46,121.09,125.75$, $126.36,127.35,128.91,129.13,129.96,130.93,135.20$, 137.55, 159.87, 173.68; IR (film) $\nu$ 3054, 2988, 2954, 2844, 1734, 1596, 1481, 1461, 1459, 1436, 1266, 1228, 1022, 986, 896, 739, $705 \mathrm{~cm}^{-1}$; $\mathrm{MS}\left(\mathrm{FAB}^{+}, \mathrm{NBA}\right)$ $m / z=283\left(\mathrm{MH}^{+}\right), 223\left(\mathrm{M}^{+}-\mathrm{CO}_{2} \mathrm{Me}\right), 177\left(\mathrm{M}^{+}-\mathrm{CH}_{2} \mathrm{Ar}\right)$, 105, 77, 39, 27; HRMS for $\mathrm{C}_{18} \mathrm{H}_{19} \mathrm{O}_{3}\left(\mathrm{MH}^{+}\right)$: calcd 283.1334 found 283.1318 .

4.1.10. 3-(3,4-Dimethoxybenzyl)-2,3-dihydrobenzofuran-3-carboxylic acid (12e). Synthesized using 3,4-dimethoxyphenylboronic acid to afford 11e (71\%). Compound 11e was transformed according to the procedure described for preparation of 12a to afford 12e $(64 \%):{ }^{1} \mathrm{H}$ NMR $\left(250 \mathrm{MHz}, \mathrm{CDCl}_{3}\right) \delta 3.07(\mathrm{~d}, 1 \mathrm{H}, J=13.8 \mathrm{~Hz}), 3.33$ $(\mathrm{d}, 1 \mathrm{H}, J=13.8 \mathrm{~Hz}), 3.58(\mathrm{~s}, 3 \mathrm{H}), 3.78(\mathrm{~s}, 3 \mathrm{H}), 4.45(\mathrm{~d}, 1 \mathrm{H}$, $J=9.5 \mathrm{~Hz}), \quad 4.83(\mathrm{~d}, \quad 1 \mathrm{H}, \quad J=9.5 \mathrm{~Hz}), \quad 6.39 \quad(\mathrm{~d}, \quad 1 \mathrm{H}$, $J=1.7 \mathrm{~Hz}), 6.61(\mathrm{dd}, 1 \mathrm{H}, J=8.0 \mathrm{~Hz}, J=1.6 \mathrm{~Hz}), 6.71(\mathrm{t}$, $2 \mathrm{H}, J=8.0 \mathrm{~Hz}), 6.89(\mathrm{t}, 1 \mathrm{H}, J=7.4 \mathrm{~Hz}), 7.17(\mathrm{t}, 1 \mathrm{H}$, $J=7.4 \mathrm{~Hz}), 7.39(\mathrm{~d}, 1 \mathrm{H}, J=7.2 \mathrm{~Hz}) ;{ }^{13} \mathrm{C}$ NMR $(100 \mathrm{MHz}$, $\left.\mathrm{CDCl}_{3}\right) \delta$ 43.65, 55.97, 56.20, 58.09, 76.50, 110.65, $111.42,113.06,121.18,122.30,125.54,128.09,128.59$, 130.31, 148.60, 149.04, 160.13, 179.36; IR (film) $\nu 3076$, $3004,2931,2832,1705,1592,1515,1478,1460,1415$, $1315,1261,1238,1152,1139,1026,971,749 \mathrm{~cm}^{-1}$; MS $\left(\mathrm{FAB}^{-}, \mathrm{NBA}\right) \mathrm{m} / \mathrm{z}=313(\mathrm{M} \bullet-\mathrm{H}), 314(\mathrm{M} \bullet), 46$; HRMS for $\mathrm{C}_{18} \mathrm{H}_{17} \mathrm{O}_{5}(\mathrm{M} \cdot-\mathrm{H})$ : calcd 313.1076 found 313.1066.

4.1.11. 3-(3,4,5-Trimethoxybenzyl)-2,3-dihydrobenzofuran-3-carboxylic acid (12f). Synthesized according to the procedure described for the preparation of 11a, using 3,4,5-dimethoxyphenylboronic acid to afford 11f (73\%). Compound 11f was transformed according to the procedure described for preparation of 12a to afford $\mathbf{1 2 f}(71 \%)$ : ${ }^{1} \mathrm{H}$ NMR $\left(250 \mathrm{MHz}, \mathrm{CDCl}_{3}\right) \delta 3.13(\mathrm{~d}, 1 \mathrm{H}, J=13.8 \mathrm{~Hz}), 3.38$ $(\mathrm{d}, 1 \mathrm{H}, J=13.8 \mathrm{~Hz}), 3.68(\mathrm{~s}, 6 \mathrm{H}), 3.81(\mathrm{~s}, 3 \mathrm{H}), 4.51(\mathrm{~d}, 1 \mathrm{H}$, $J=9.5 \mathrm{~Hz}), 4.91(\mathrm{~d}, 1 \mathrm{H}, J=9.5 \mathrm{~Hz}), 6.23(\mathrm{~s}, 2 \mathrm{H}), 6.80(\mathrm{~d}$, $1 \mathrm{H}, J=8.0 \mathrm{~Hz}), 6.96(\mathrm{t}, 1 \mathrm{H}, J=7.5 \mathrm{~Hz}), 7.23(\mathrm{t}, 1 \mathrm{H}$, $J=7.9 \mathrm{~Hz}), 7.44(\mathrm{~d}, 1 \mathrm{H}, J=7.5 \mathrm{~Hz}) ;{ }^{13} \mathrm{C}$ NMR $(100 \mathrm{MHz}$, $\left.\mathrm{CDCl}_{3}\right) \delta$ 44.21, 56.33, 58.00, 61.26, 76.49, 107.13, $110.67,121.20,125.51,128.07,130.37,131.80,137.51$, 153.39, 160.09, 178.95; IR (film) $\nu$ 3079, 3000, 2940, 2838, 1731, 1704, 1592, 1510, 1482, 1462, 1423, 1337, $1239,1128,1004,977,833,755 \mathrm{~cm}^{-1}$; MS (FAB $\left.{ }^{-}, \mathrm{NBA}\right)$ 
$m / z=343(\mathrm{M} \bullet-\mathrm{H}), 299,46$; HRMS for $\mathrm{C}_{19} \mathrm{H}_{19} \mathrm{O}_{6}(\mathrm{M} \bullet-\mathrm{H})$ : calcd 343.1182 found 343.1194 .

\subsubsection{3-(2-Chlorobenzyl)-2,3-dihydrobenzofuran-3-} carboxylic acid (12g). Synthesized according to the procedure described for the preparation of 11a, using 2chlorophenylboronic acid to afford $\mathbf{1 1 g}(66 \%)$. Compound $11 \mathrm{~g}$ was transformed according to the procedure described for preparation of 12a to afford 12g (70\%): ${ }^{1} \mathrm{H}$ NMR $\left(250 \mathrm{MHz}, \mathrm{CDCl}_{3}\right) \delta 3.36(\mathrm{~d}, 1 \mathrm{H}, J=14.4 \mathrm{~Hz}, \mathrm{H}), 3.63(\mathrm{~d}$, $1 \mathrm{H}, J=14.4 \mathrm{~Hz}, \mathrm{H}), 4.48(\mathrm{~d}, 1 \mathrm{H}, J=9.6 \mathrm{~Hz}), 4.90(\mathrm{~d}, 1 \mathrm{H}$ $J=9.6 \mathrm{~Hz}), 6.74(\mathrm{~d}, 1 \mathrm{H}, J=8.0 \mathrm{~Hz}), 6.87-6.92(\mathrm{~m}, 2 \mathrm{H})$, 7.00-7.18 (m, 3H), 7.27-7.38 (m, 2H); ${ }^{13} \mathrm{C} \quad \mathrm{NMR}$ $\left(100 \mathrm{MHz}, \mathrm{CDCl}_{3}\right) \delta 39.96,57.59,76.56,110.65,121.27$, $125.63,127.21,127.86,128.96,130.22,130.43,131.30$, $134.30,135.43,160.10,179.21$ (CO); IR (film) $\nu 3064$, $3024,2961,2850,1703,1595,1480,1461,1443,1317$, 1288, 1239, 1162, 1131, 1022, 975, 834, 751, $678 \mathrm{~cm}^{-1}$; MS $\left(\mathrm{FAB}^{-}, \mathrm{NBA}\right) m / z=287(\mathrm{M} \bullet-\mathrm{H}), 243\left(\mathrm{M} \bullet-\mathrm{CO}_{2} \mathrm{H}\right)$, 223, 46; HRMS for $\mathrm{C}_{16} \mathrm{H}_{12} \mathrm{O}_{3}{ }^{35} \mathrm{Cl}(\mathrm{M} \bullet-\mathrm{H})$ : calcd 287.0475 found 287.0468 .

4.1.13. 3-(3-Chlorobenzyl)-2,3-dihydrobenzofuran-3carboxylic acid (12h). Synthesized according to the procedure described for the preparation of 11a, using 3chlorophenylboronic acid to afford $\mathbf{1 1 h}(78 \%)$. Compound 11h was transformed according to the procedure described for preparation of 12a to afford 12h $(78 \%)$ : ${ }^{1} \mathrm{H}$ NMR $\left(250 \mathrm{MHz}, \mathrm{CDCl}_{3}\right) \delta 3.08(\mathrm{~d}, 1 \mathrm{H}, J=13.8 \mathrm{~Hz}), 3.41(\mathrm{~d}$, $1 \mathrm{H}, J=13.8 \mathrm{~Hz}), 4.44(\mathrm{~d}, 1 \mathrm{H}, J=9.6 \mathrm{~Hz}), 4.85(\mathrm{~d}, 1 \mathrm{H}$, $J=9.6 \mathrm{~Hz}), 6.76(\mathrm{~d}, 1 \mathrm{H}, J=8.0 \mathrm{~Hz}), 6.91 \quad(\mathrm{t}, 2 \mathrm{H}, \quad J=$ $7.5 \mathrm{~Hz}), 7.00(\mathrm{~s}, 1 \mathrm{H}), 7.09-7.19(\mathrm{~m}, 3 \mathrm{H}), 7.33(\mathrm{~d}, 1 \mathrm{H}$, $J=6.1 \mathrm{~Hz}) ;{ }^{13} \mathrm{C}$ NMR $\left(100 \mathrm{MHz}, \mathrm{CDCl}_{3}\right) \delta 43.50,57.82$, $76.53,110.70,121.37,125.41,127.83,127.89,128.32$, $130.14,130.25,130.52,134.69,138.22,159.97,178.56$; IR (film) $\nu$ 3080, 3022, 2959, 2926, 2851, 1704, 1596, $1573,1481,1462,1430,1409,1316,1277,1239,1209$, 1082, 1022, 976, 833, 793, 752, $684 \mathrm{~cm}^{-1}$; MS $\left(\mathrm{FAB}^{-}\right.$, NBA) $m / z=287(\mathrm{M} \cdot-\mathrm{H}), 243\left(\mathrm{M} \cdot-\mathrm{CO}_{2} \mathrm{H}\right), 223,46$; HRMS for $\mathrm{C}_{16} \mathrm{H}_{12} \mathrm{O}_{3}{ }^{35} \mathrm{Cl}(\mathrm{M} \cdot-\mathrm{H})$ : calcd 287.0475 found 287.0474 .

4.1.14. 3-(4-Chlorobenzyl)-2,3-dihydrobenzofuran-3carboxylic acid (12i). Synthesized according to the procedure described for the preparation of 11a, using 4chlorophenylboronic acid to afford 11i $(65 \%)$. Compound 11i was transformed according to the procedure described for preparation of 12a to afford 12i $(65 \%)$ : ${ }^{1} \mathrm{H}$ NMR $\left(250 \mathrm{MHz}, \mathrm{CDCl}_{3}\right) \delta 3.13(\mathrm{~d}, 1 \mathrm{H}, J=13.8 \mathrm{~Hz}), 3.43(\mathrm{~d}$, $1 \mathrm{H}, J=14.0 \mathrm{~Hz}), 4.47(\mathrm{~d}, 1 \mathrm{H}, J=9.6 \mathrm{~Hz}), 4.88(\mathrm{~d}, 1 \mathrm{H}$, $J=9.6 \mathrm{~Hz}), 6.80(\mathrm{~d}, 1 \mathrm{H}, J=8.1 \mathrm{~Hz}), 6.91-7.00(\mathrm{~m}, 3 \mathrm{H})$, 7.15-7.26 (m, 3H), $7.40(\mathrm{~d}, 1 \mathrm{H}, J=7.6 \mathrm{~Hz}) ;{ }^{13} \mathrm{C}$ NMR $\left(100 \mathrm{MHz}, \mathrm{CDCl}_{3}\right) \delta 43.21,57.89,76.51,110.70,121.35$, $125.44,127.78,129.07,130.49$, 131.39, 133.66, 134.64, 159.96, 179.03; IR (film) $\nu$ 3084, 3028, 2952, 2925, 2884, $1704,1596,1481,1462,1408,1317,1296,1238,1094$, 1016, 975, $835 \mathrm{~cm}^{-1}$; MS (FAB $\left.{ }^{-}, \mathrm{NBA}\right) \mathrm{m} / z=287$ $(\mathrm{M} \cdot-\mathrm{H}), \quad 243\left(\mathrm{M} \cdot-\mathrm{CO}_{2} \mathrm{H}\right), \quad 223, \quad 46$; HRMS for $\mathrm{C}_{16} \mathrm{H}_{12} \mathrm{O}_{3}{ }^{35} \mathrm{Cl}(\mathrm{M} \cdot-\mathrm{H})$ : calcd 287.0475 found 287.0475 .

4.1.15. 3-(3,4-Dichlorobenzyl)-2,3-dihydrobenzofuran-3carboxylic acid (12j). Synthesized according to the procedure described for the preparation of 11a, using 3,4-dichlorophenylboronic acid to afford $\mathbf{1 1} \mathbf{j}$ (85\%). Compound $11 \mathbf{j}$ was transformed according to the procedure described for preparation of 12a to afford $\mathbf{1 2} \mathbf{j}(69 \%)$ : ${ }^{1} \mathrm{H}$ NMR $\left(250 \mathrm{MHz}, \mathrm{CDCl}_{3}\right) \delta 3.09(\mathrm{~d}, 1 \mathrm{H}, J=13.8 \mathrm{~Hz}), 3.35$ $(\mathrm{d}, 1 \mathrm{H}, J=13.8 \mathrm{~Hz}), 4.42(\mathrm{~d}, 1 \mathrm{H}, J=9.6 \mathrm{~Hz}), 4.85(\mathrm{~d}, 1 \mathrm{H}$, $J=9.6 \mathrm{~Hz}), 6.72-6.85(\mathrm{~m}, 2 \mathrm{H}), 6.92(\mathrm{t}, 1 \mathrm{H}, J=7.4 \mathrm{~Hz})$, $7.09(\mathrm{~d}, 1 \mathrm{H}, J=2.0 \mathrm{~Hz}), 7.18-7.27(\mathrm{~m}, 2 \mathrm{H}), 7.35(\mathrm{~d}, 1 \mathrm{H}$, $J=7.5 \mathrm{~Hz}) ;{ }^{13} \mathrm{C}$ NMR $\left(100 \mathrm{MHz}, \mathrm{CDCl}_{3}\right) \delta 42.85,57.73$, $76.44,110.79,121.45,125.34,127.47,129.40,130.67$, $130.79,131.93,132.06,132.85,136.35,159.95,178.69$; IR (film) $\nu$ 3065, 2993, 2954, 2929, 1704, 1595, 1481, $1462,1398,1316,1279,1238,1134,1032,977,834$, $756 \mathrm{~cm}^{-1}$; MS (FAB ${ }^{-}$, NBA) $\mathrm{m} / z=321(\mathrm{M} \bullet-\mathrm{H}), 277$ $\left(\mathrm{M} \bullet-\mathrm{CO}_{2} \mathrm{H}\right), 46$; HRMS for $\mathrm{C}_{16} \mathrm{H}_{11} \mathrm{O}_{3}{ }^{35} \mathrm{Cl}_{2}(\mathrm{M} \bullet-\mathrm{H})$ : calcd 321.0085 found 321.0076 .

4.1.16. 3-(2-Trifluoromethylbenzyl)-2,3-dihydrobenzofuran-3-carboxylic acid (12k). Synthesized according to the procedure described for the preparation of 11a, using 2-(trifluoromethyl)phenylboronic acid to afford 11k (49\%). Compound $11 \mathbf{k}$ was transformed according to the procedure described for preparation of 12a to afford $12 \mathbf{k}(55 \%)$ : ${ }^{1} \mathrm{H}$ NMR $\left(250 \mathrm{MHz}, \mathrm{CDCl}_{3}\right) \delta 3.42(\mathrm{~d}, 1 \mathrm{H}, J=15.8 \mathrm{~Hz}), 3.78$ $(\mathrm{d}, 1 \mathrm{H}, J=15.6 \mathrm{~Hz}), 4.26(\mathrm{~d}, 1 \mathrm{H}, J=9.7 \mathrm{~Hz}), 5.02(\mathrm{~d}, 1 \mathrm{H}$, $J=9.7 \mathrm{~Hz}), 6.77(\mathrm{~d}, 1 \mathrm{H}, J=8.1 \mathrm{~Hz}), 6.93(\mathrm{t}, 2 \mathrm{H}, J=$ $7.4 \mathrm{~Hz}), 7.18-7.25(\mathrm{~m}, 1 \mathrm{H}), 7.29-7.32(\mathrm{~m}, 2 \mathrm{H}), 7.39(\mathrm{~d}$, $1 \mathrm{H}, \quad J=7.6 \mathrm{~Hz}), 7.63(\mathrm{~d}, 1 \mathrm{H}, \quad J=6.2 \mathrm{~Hz}) ;{ }^{13} \mathrm{C} \quad \mathrm{NMR}$ $\left(100 \mathrm{MHz}, \mathrm{CDCl}_{3}\right) \delta 38.78,56.90,76.68,110.74,121.42$, $126.05,126.87,126.93,127.53,128.01,130.07,130.36$, 130.67, 132.28, 135.41, 160.04, 179.37 (CO); IR (film) $\nu$ 3073, 3007, 2954, 2908, 1704, 1608, 1596, 1482, 1462, 1312, 1240, 1167, 1120, 1062, 1039, 1022, 975, 837, 769, $755 \mathrm{~cm}^{-1}$; MS (FAB ${ }^{-}$, NBA) $m / z=321(\mathrm{M} \bullet-\mathrm{H}), 277$ $\left(\mathrm{M} \bullet-\mathrm{CO}_{2} \mathrm{H}\right), 46$; HRMS for $\mathrm{C}_{17} \mathrm{H}_{12} \mathrm{O}_{3} \mathrm{~F}_{3}(\mathrm{M} \bullet-\mathrm{H})$ : calcd 321.0739 found 321.0749 .

4.1.17. 3-(4-Trifluoromethoxybenzyl)-2,3-dihydrobenzofuran-3-carboxylic acid (12I). Synthesized according to the procedure described for the preparation of 11a, using 4-(trifluoroacetyl)phenylboronic acid to afford 111 (66\%). Compound $\mathbf{1 1 l}$ was transformed according to the procedure described for preparation of 12a to afford $\mathbf{1 2 l}(73 \%)$ : ${ }^{1} \mathrm{H}$ NMR $\left(250 \mathrm{MHz}, \mathrm{CDCl}_{3}\right) \delta 3.11(\mathrm{~d}, 1 \mathrm{H}, J=13.9 \mathrm{~Hz}), 3.43$ $(\mathrm{d}, 1 \mathrm{H}, J=13.9 \mathrm{~Hz}), 4.43(\mathrm{~d}, 1 \mathrm{H}, J=9.6 \mathrm{~Hz}), 4.85(\mathrm{~d}, 1 \mathrm{H}$, $J=9.6 \mathrm{~Hz}), 6.75(\mathrm{~d}, 1 \mathrm{H}, J=8.0 \mathrm{~Hz}), 6.91(\mathrm{t}, 1 \mathrm{H}, J=$ $7.5 \mathrm{~Hz}), 7.03(\mathrm{~s}, 4 \mathrm{H}), 7.17(\mathrm{td}, 1 \mathrm{H}, J=7.6 \mathrm{~Hz}, J=1.3 \mathrm{~Hz})$, $7.34(\mathrm{~d}, 1 \mathrm{H}, J=6.4 \mathrm{~Hz}) ;{ }^{13} \mathrm{C}$ NMR $\left(100 \mathrm{MHz}, \mathrm{CDCl}_{3}\right)$ $\delta 43.08,57.87,76.53,110.71,121.29,121.36,125.37$, $127.81,128.89,130.52,131.42,134.91,148.86,159.95$, 178.88; IR (film) $\nu$ 3046-2931, 1704, 1596, 1510, 1482, $1462,1416,1258,1222,1166,1111,1021,976,835$, $753 \mathrm{~cm}^{-1}$; MS (FAB ${ }^{-}$, NBA) $m / z=337(\mathrm{M} \bullet-\mathrm{H}), 293$ $\left(\mathrm{M} \bullet-\mathrm{CO}_{2} \mathrm{H}\right), 46$; HRMS for $\mathrm{C}_{17} \mathrm{H}_{12} \mathrm{O}_{4} \mathrm{~F}_{3}(\mathrm{M} \bullet-\mathrm{H})$ : calcd 337.0688 found 337.0679 .

4.1.18. 3-(4-Acetylbenzyl)-2,3-dihydrobenzofuran-3-carboxylic acid (12m). Synthesized according to the procedure described for the preparation of 11a, using 4-acetylphenylboronic acid to afford $\mathbf{1 1 m}$ (73\%). Compound $\mathbf{1 1 m}$ was transformed according to the procedure described for preparation of 12a to afford 12m (70\%): ${ }^{1} \mathrm{H}$ NMR $(250 \mathrm{MHz}$, $\left.\mathrm{CDCl}_{3}\right) \delta 2.57(\mathrm{~s}, 3 \mathrm{H}), 3.22(\mathrm{~d}, 1 \mathrm{H}, J=13.7 \mathrm{~Hz}), 3.52(\mathrm{~d}$, $1 \mathrm{H}, J=13.7 \mathrm{~Hz}), 4.48(\mathrm{~d}, 1 \mathrm{H}, J=9.6 \mathrm{~Hz}), 4.89(\mathrm{~d}, 1 \mathrm{H}$, 
$J=9.6 \mathrm{~Hz}), 6.78(\mathrm{~d}, 1 \mathrm{H}, J=8.1 \mathrm{~Hz}), 6.95(\mathrm{t}, 1 \mathrm{H}, J=7.2 \mathrm{~Hz})$, $7.14(\mathrm{~d}, 2 \mathrm{H}, J=8.2 \mathrm{~Hz}), 7.22(\mathrm{t}, 1 \mathrm{H}, J=7.6 \mathrm{~Hz}), 7.41(\mathrm{~d}, 1 \mathrm{H}$, $J=7.6 \mathrm{~Hz}), 7.83(\mathrm{~d}, 2 \mathrm{H}, J=8.2 \mathrm{~Hz},) ;{ }^{13} \mathrm{C}$ NMR $(100 \mathrm{MHz}$, $\left.\mathrm{CDCl}_{3}\right) \delta$ 26.98, 43.79, 57.75, 76.58, 110.70, 121.37, $125.43,127.85,128.89,128.96,130.37,130.50,136.37$, 141.99, 159.95, 178.11, 198.70; IR (film) $\nu$ 3054-2931, 1731, 1704, 1682, 1607, 1571, 1481, 1461, 1415, 1360, 1268, 1238, 1186, 1119, 1021, 973, 835, 753, 737, $703 \mathrm{~cm}^{-1}$; MS (FAB $\left.{ }^{-}, \mathrm{NBA}\right) \mathrm{m} / z=295(\mathrm{M} \bullet-\mathrm{OH})$.

4.1.19. 3-[4-(1,3,6-Trioxaheptane)benzyl]-2,3-dihydrobenzofuran-3-carboxylic acid (12n). Synthesized according to the procedure described for the preparation of 11a, using 4-(1,3,6-trioxaheptane)phenylboronic acid to afford 11n (79\%). Compound 11n was transformed according to the procedure described for preparation of $\mathbf{1 2 a}$ to afford 12n $(91 \%):{ }^{1} \mathrm{H}$ NMR $\left(250 \mathrm{MHz}, \mathrm{CDCl}_{3}\right) \delta 3.09(\mathrm{~d}, 1 \mathrm{H}$, $J=13.9 \mathrm{~Hz}), 3.37$ (s, 3H), 3.45 (d, 1H, J=13.9 Hz), 3.54$3.57(\mathrm{~m}, 2 \mathrm{H}), 3.79-3.83(\mathrm{~m}, 2 \mathrm{H}), 4.50(\mathrm{~d}, 1 \mathrm{H}, J=9.5 \mathrm{~Hz})$, $4.88(\mathrm{~d}, 1 \mathrm{H}, J=9.5 \mathrm{~Hz}), 6.79(\mathrm{~d}, 1 \mathrm{H}, J=8.0 \mathrm{~Hz}), 6.90-7.01$ $(\mathrm{m}, 5 \mathrm{H}), 7.22(\mathrm{td}, 1 \mathrm{H}, J=7.8 \mathrm{~Hz}, J=1.4 \mathrm{~Hz}), 742(\mathrm{dd}, 1 \mathrm{H}$, $J=7.5 \mathrm{~Hz}, \quad J=1.1 \mathrm{~Hz}) ;{ }^{13} \mathrm{C} \quad \mathrm{NMR} \quad\left(100 \mathrm{MHz}, \mathrm{CDCl}_{3}\right)$ $\delta$ 43.18, 58.05, 59.36, 68.01, 72.01, 76.59, 93.85, 110.54, $116.63,116.68,121.08,125.48,128.34,129.64,129.69$, 130.22, 131.12, 156.82, 159.96, 178.48; IR (film) $\nu 3165$, 3015, 2923, 2908, 2822, 1731, 1704, 1610, 1596, 1511, 1481, 1461, 1398, 1367, 1314, 1224, 1180, 1165, 1098, 1003, $836 \mathrm{~cm}^{-1}$; MS (FAB $\left.{ }^{-}, \mathrm{NBA}\right) \mathrm{m} / z=357(\mathrm{M} \bullet-\mathrm{H})$, $313\left(\mathrm{M} \bullet-\mathrm{CO}_{2} \mathrm{H}\right), 46$; HRMS for $\mathrm{C}_{20} \mathrm{H}_{21} \mathrm{O}_{6}(\mathrm{M} \bullet-\mathrm{H})$ : calcd 357.1338 found 357.1340 .

4.1.20. 3-(4-Vinylbenzyl)-2,3-dihydrobenzofuran-3-carboxylic acid (120). Synthesized according to the procedure described for the preparation of 11a, using 4-vinylphenylboronic acid to afford $110(53 \%)$. Compound 110 was transformed according to the procedure described for preparation of 12a to afford $120(95 \%):{ }^{1} \mathrm{H}$ NMR $\left(250 \mathrm{MHz}, \mathrm{CDCl}_{3}\right)$ $\delta 3.14(\mathrm{~d}, 1 \mathrm{H}, J=13.8 \mathrm{~Hz}), 3.50(\mathrm{~d}, 1 \mathrm{H}, J=13.8 \mathrm{~Hz}), 4.51$ $(\mathrm{d}, 1 \mathrm{H}, J=9.5 \mathrm{~Hz}), 4.89(\mathrm{~d}, 1 \mathrm{H}, J=9.5 \mathrm{~Hz}), 5.23(\mathrm{dd}, 1 \mathrm{H}$, $J=10.9 \mathrm{~Hz}, \quad J=0.6 \mathrm{~Hz}), \quad 5.71 \quad(\mathrm{dd}, \quad 1 \mathrm{H}, \quad J=17.6 \mathrm{~Hz}$, $J=0.7 \mathrm{~Hz}), 6.67(\mathrm{q}, 1 \mathrm{H}, J=17.6 \mathrm{~Hz}, J=10.9 \mathrm{~Hz}), 6.80(\mathrm{~d}$, $1 \mathrm{H}, J=8.1 \mathrm{~Hz}), 6.95(\mathrm{td}, 1 \mathrm{H}, J=7.5 \mathrm{~Hz}, J=0.9 \mathrm{~Hz}), 7.04$ $(\mathrm{d}, 2 \mathrm{H}, J=8.2 \mathrm{~Hz}), 7.20-7.31(\mathrm{~m}, 3 \mathrm{H}), 7.43(\mathrm{dd}, 1 \mathrm{H}$, $J=7.5 \mathrm{~Hz}, \quad J=1.3 \mathrm{~Hz}) ;{ }^{13} \mathrm{C} \quad \mathrm{NMR} \quad\left(100 \mathrm{MHz}, \mathrm{CDCl}_{3}\right)$ $\delta$ 43.73, 58.00, 76.60, 110.62, 114.31, 121.27, 125.52, $126.76,127.00,128.20,130.24,130.33,135.87,136.69$, 136.78, 136.87, 159.97, 178.97; IR (film) $\nu$ 3086, 3023, 2953, 2924, 1704, 1630, 1596, 1512, 1481, 1462, 1407, 1316, 1294, 1239, 1119, 1099, 1021, 974, 912, $835 \mathrm{~cm}^{-1}$; MS (FAB $\left.{ }^{-}, \mathrm{NBA}\right) m / z=279(\mathrm{M} \bullet-\mathrm{H}), 235\left(\mathrm{M} \bullet-\mathrm{CO}_{2} \mathrm{H}\right)$, 46; HRMS for $\mathrm{C}_{18} \mathrm{H}_{15} \mathrm{O}_{3}(\mathrm{M} \bullet-\mathrm{H})$ : calcd 279.1021 found 279.1029 .

4.1.21. 3-(1-Methylenylnaphtyl)-2,3-dihydrobenzofuran3-carboxylic acid (12p). Synthesized according to the procedure described for the preparation of 11a, using 1naphtylboronic acid to afford 11p (78\%). Compound 11p was transformed according to the procedure described for preparation of $\mathbf{1 2 a}$ to afford 12p $(50 \%)$ : ${ }^{1} \mathrm{H} \quad \mathrm{NMR}$ $\left(250 \mathrm{MHz}, \mathrm{CDCl}_{3}\right) \delta 3.26(\mathrm{~d}, 1 \mathrm{H}, J=13.8 \mathrm{~Hz}), 3.64(\mathrm{~d}$, $1 \mathrm{H}, J=13.8 \mathrm{~Hz}), 4.54(\mathrm{~d}, 1 \mathrm{H}, J=9.6 \mathrm{~Hz}), 4.87(\mathrm{~d}, 1 \mathrm{H}, J=$ $9.6 \mathrm{~Hz}), 6.76(\mathrm{~d}, 1 \mathrm{H}, J=8.1 \mathrm{~Hz}), 6.93(\mathrm{t}, 1 \mathrm{H}, J=7.1 \mathrm{~Hz})$, 7.12-7.24 (m, 2H), 7.39-7.44 (m, 3H), 7.50 (s, 1H), 7.63- $7.69(\mathrm{~m}, 1 \mathrm{H}), 7.73-7.77(\mathrm{~m}, 1 \mathrm{H}) ;{ }^{13} \mathrm{C}$ NMR $(100 \mathrm{MHz}$ $\left.\mathrm{CDCl}_{3}\right) \delta$ 44.18, 58.07, 76.65, 110.66, 121.31, 125.56, $126.28,126.60,128.00,128.03,128.12,128.32,128.58$, $128.99,130.37,132.89,133.75,133.86,159.99,178.93$; IR (film) $\nu$ 3054-2860, 1704, 1596, 1508, 1481, 1461, 1367, 1315, 1239, 1154, 1099, 1022, 975, 821, $751 \mathrm{~cm}^{-1}$; MS (FAB $\left.{ }^{-}, \mathrm{NBA}\right) m / z=303(\mathrm{M} \bullet-\mathrm{H}), 259\left(\mathrm{M} \bullet-\mathrm{CO}_{2} \mathrm{H}\right)$, 46; HRMS for $\mathrm{C}_{20} \mathrm{H}_{15} \mathrm{O}_{3}(\mathrm{M} \bullet-\mathrm{H})$ : calcd 303.1021 found 303.1010 .

4.1.22. 3-(5,5,8,8-Tetramethyl-5,6,7,8-tetrahydro-2methylenylnaphtyl)-2,3-dihydrobenzofuran-3-carboxylic acid (12q). Synthesized according to the procedure described for the preparation of 11a, using 5,5,8,8-tetramethyl-5,6,7,8-tetrahydro-2-naphtylboronic acid to afford 11q $(81 \%)$. Compound 11q was transformed according to the procedure described for preparation of 12a to afford 12 (88\%): ${ }^{1} \mathrm{H} \mathrm{NMR}\left(250 \mathrm{MHz}, \mathrm{CDCl}_{3}\right) \delta 1.136$ and $1.143(2 \mathrm{~s}$, $6 \mathrm{H}), 1.25(\mathrm{~s}, 6 \mathrm{H}), 1.63(\mathrm{~s}, 4 \mathrm{H}), 3.09(\mathrm{~d}, 1 \mathrm{H}, J=13.8 \mathrm{~Hz})$, $3.46(\mathrm{~d}, 1 \mathrm{H}, J=13.8 \mathrm{~Hz}), 4.50(\mathrm{~d}, 1 \mathrm{H}, J=9.5 \mathrm{~Hz}), 4.90(\mathrm{~d}$, $1 \mathrm{H}, J=9.5 \mathrm{~Hz}), 6.80(\mathrm{~d}, 1 \mathrm{H}, J=8.0 \mathrm{~Hz}), 6.86-6.97(\mathrm{~m}, 4 \mathrm{H})$, $7.17-7.19(\mathrm{~m}, 1 \mathrm{H}), 7.44(\mathrm{dd}, 1 \mathrm{H}, J=7.6 \mathrm{~Hz}, J=1.1 \mathrm{~Hz})$; ${ }^{13} \mathrm{C}$ NMR $\left(100 \mathrm{MHz}, \mathrm{CDCl}_{3}\right) \delta 31.99,32.12,32.23,32.30$, 34.39 , 34.47, 35.41, 35.42, 43.76, 58.03, 76.64, 110.52, $121.18,125.58,127.03,127.22,128.18,128.39,130.17$, 133.02, 144.08, 145.29, 159.97, 179.16; $\mathrm{MS}_{\left(\mathrm{FAB}^{-}, \mathrm{NBA}\right)}$ $m / z=363(\mathrm{M} \bullet-\mathrm{H}), 319\left(\mathrm{M} \bullet-\mathrm{CO}_{2} \mathrm{H}\right), 46$.

4.1.23. 3-(4-Phenylbenzyl)-3-methoxycarbonyl-2,3-dihydrobenzofuran (11r). Synthesized according to the procedure described for the preparation of 11a, using 4biphenylboronic acid, followed by column chromatography (silica gel, hexane/ $\left.\mathrm{CH}_{2} \mathrm{Cl}_{2}: 1 / 1\right)$ afforded $11 \mathbf{r}(71 \%$ and $57 \%$ one-pot version): ${ }^{1} \mathrm{H}$ NMR $\left(250 \mathrm{MHz}, \mathrm{CDCl}_{3}\right) \delta 3.20(\mathrm{~d}, 1 \mathrm{H}$, $J=13.7 \mathrm{~Hz}), 3.57$ (d, 1H, $J=13.7 \mathrm{~Hz}), 3.82$ (s, 3H) 4.60 (d, $1 \mathrm{H}, J=9.5 \mathrm{~Hz}), 4.98(\mathrm{~d}, 1 \mathrm{H}, J=9.5 \mathrm{~Hz}), 6.86(\mathrm{~d}, 1 \mathrm{H}$, $J=8 \mathrm{~Hz}), 6.99(\mathrm{td}, 1 \mathrm{H}, J=7.4 \mathrm{~Hz}, J=0.8 \mathrm{~Hz}), 7.15(\mathrm{~d}, 2 \mathrm{H}$, $J=8.2 \mathrm{~Hz}), 7.27(\mathrm{td}, 1 \mathrm{H}, J=8.6 \mathrm{~Hz}, J=1.4 \mathrm{~Hz}), 7.39-7.56$ $(\mathrm{m}, 6 \mathrm{H}), 7.62(\mathrm{~d}, 2 \mathrm{H}, J=7.0 \mathrm{~Hz}) ;{ }^{13} \mathrm{C} \mathrm{NMR}(100 \mathrm{MHz}$, $\left.\mathrm{CDCl}_{3}\right) \delta$ 44.10, 53.00, 58.14, 77.06, 110.54, 121.14, $125.53,127.41,127.53,127.71,128.82,129.19,130.07$, $130.44,135.66,140.36,141.05,159.97,173.31$; IR (film) $\nu$ 3063, 3030, 2954, 2928, 2855, 1732, 1596, 1481, 1460, $1435,1409,1328,1314,1298,1276,1228,1118,1097$, $1076,1022,1008,981,880,836,763,699 \mathrm{~cm}^{-1} ; \mathrm{MS}$ $\left(\mathrm{FAB}^{+}, \mathrm{NBA}\right) m / z=573,483,392,366,345\left(\mathrm{MH}^{+}\right), 344$ $\left(\mathrm{M}^{+}\right)$, 307, 289, 167, 91, 55, 41; HRMS for $\mathrm{C}_{23} \mathrm{H}_{21} \mathrm{O}_{3}$ $\left(\mathrm{MH}^{+}\right)$: calcd 345.1491 found 345.1500.

\section{Acknowledgements}

We thank Galderma S. A. (Sophia-Antipolis) and the CNRS for financial support. We thank Yann Brouillette for his help in proof-reading the manuscript.

\section{References and notes}

1. Jarvis, B. B.; Pena, N. B.; Comezoglu, S. N.; Rao, M. M. Phytochemistry 1986, 25, 533-535.

2. Achenbach, H.; Utz, W.; Usubillaga, A.; Rodriguez, H. A. Phytochemistry 1991, 30, 3753-3757. 
3. Saito, T.; Suzuki, T.; Morimoto, M.; Akiyama, C.; Ochiai, T.; Takeuchi, K.; Matsumoto, T.; Suzuki, K. J. Am. Chem. Soc. 1998, 120, 11633-11644.

4. Van Miert, S.; Van Dyck, S.; Schmidt, T. J.; Brun, R.; Vlietinck, A.; Lemiere, G.; Pieters, L. Bioorg. Med. Chem. 2005, 13, 661-669.

5. Wolfe, J. P.; Thomas, J. S. Curr. Org. Chem. 2005, 9, 625-655.

6. Tietze, L. F. Chem. Rev. 1996, 96, 115-136.

7. Kuethe, J. T.; Wong, A.; Journet, M.; Davies, I. W. J. Org. Chem. 2005, 70, 3727-3729.

8. Park, D. Y.; Gowrisankar, S.; Kim, J. N. Bull. Korean Chem. Soc. 2005, 26, 1440-1442.

9. Nakamura, I.; Yamamoto, Y. Chem. Rev. 2004, 104, 2127-2198.

10. De Meijere, A.; Nuske, H.; Es-Sayed, M.; Labahn, T.; Schroen, M.; Brase, S. Angew. Chem., Int. Ed. 1999, 38, 3669-3672.

11. Grigg, R.; Sridharan, V. Pure Appl. Chem. 1998, 70, 10471057.

12. Negishi, E.-i. Pure Appl. Chem. 1992, 64, 323-334.

13. Handbook of Organopalladium Chemistry for Organic Synthesis; Negishi, E.-i., Ed.; Wiley: New York, NY, 2002; Vol. 2.

14. Poli, G.; Giambastiani, G.; Heumann, A. Tetrahedron 2000, 56, 5959-5989.

15. Balme, G.; Bossharth, E.; Monteiro, N. Eur. J. Org. Chem. 2003, 4101-4111.
16. Diaz, P.; Gendre, F.; Stella, L.; Charpentier, B. Tetrahedron 1998, 54, 4579-4590.

17. Grigg, R.; Mariani, E.; Sridharan, V. Tetrahedron Lett. 2001, 42, 8677-8680.

18. Sauvagnat, B.; Lamaty, F.; Lazaro, R.; Martinez, J. Tetrahedron 2001, 57, 9711-9718.

19. Szlosek-Pinaud, M.; Diaz, P.; Martinez, J.; Lamaty, F. Tetrahedron Lett. 2003, 44, 8657-8659.

20. Roy, O.; Riahi, A.; Henin, F.; Muzart, J. Tetrahedron 2000, 56, 8133-8140.

21. Jeffery, T. Tetrahedron 1996, 52, 10113-10130.

22. Reetz, M. T.; Westermann, E. Angew. Chem., Int. Ed. 2000, 39, $165-168$.

23. Compounds 11e-o and 11q were hydrolyzed directly without characterization.

24. Gaudin, J. M. Tetrahedron Lett. 1991, 32, 6113-6116.

25. Giambastiani, G.; Pacini, B.; Porcelloni, M.; Poli, G. J. Org. Chem. 1998, 63, 804-807.

26. Lemaire, S.; Prestat, G.; Giambastiani, G.; Madec, D.; Pacini, B.; Poli, G. J. Organomet. Chem. 2003, 687, 291-300.

27. Poli, G.; Giambastiani, G. J. Org. Chem. 2002, 67, 94569459.

28. Tietze, L. F.; Nordmann, G. Eur. J. Org. Chem. 2001, 32473253. 